\title{
$\mathrm{U}-\mathrm{Pb}$ detrital zircon ages of Upper Jurassic continental successions: implications for the provenance and absolute age of the Jurassic-Cretaceous boundary in the Neuquén Basin
}

\author{
MAXIMILIANO NAIPAUER ${ }^{1,2 *}$, MAISA TUNIK ${ }^{2,3}$, JULIANA C. MARQUES ${ }^{4}$, EMILIO \\ A. ROJAS VERA ${ }^{1,2}$, GRACIELA I. VUJOVICH ${ }^{1,2}$, MARCIO M. PIMENTEL $^{4} \&$ \\ VICTOR A. RAMOS ${ }^{1,2}$ \\ ${ }^{1}$ Instituto de Estudios Andinos 'Don Pablo Groeber', Departamento de Ciencias Geológicas, \\ FCEN - Universidad de Buenos Aires, Argentina \\ ${ }^{2}$ CONICET \\ ${ }^{3}$ Instituto de Investigación en Paleobiología y Geología, Sede Alto Valle, \\ Universidad Nacional de Río Negro \\ ${ }^{4}$ Laboratorio de Geología Isotópica, Universidade Federal do Rio Grande do Sul, Brasil \\ *Corresponding author (e-mail: maxinaipauer@gl.fcen.uba.ar)
}

\begin{abstract}
New U-Pb detrital zircon ages are presented for the Tordillo Formation. The ages indicate that the most important source region of sediment supply was the Jurassic Andean arc (peaks at c. 144, 153 and $178 \mathrm{Ma}$ ), although two secondary sources were defined at c. 218 and $275 \mathrm{Ma}$. Temporal variation in the provenance indicates that at the beginning of the sedimentation, Carboniferous to Lower Jurassic magmatic rocks and Lower Palaeozoic metamorphic rocks were the most important sources. Towards the top, the data suggest that the Andean arc becomes the main source region. The comparison between provenance patterns of the Tordillo Formation and of the Avilé Member (Agrio Formation) showed some differences. In the former, the arc region played a considerable role as a source region, but this is not identified in the latter. The results permit a statistically robust estimation of the maximum deposition age for the Tordillo Formation at $c .144 \mathrm{Ma}$. This younger age represents a discrepancy of at least $7 \mathrm{Ma}$ from the absolute age of the Kimmeridgian and Tithonian boundary (from the chronostratigraphic timescale accepted by the International Commission of Stratigraphy, IUGS), and has strong implications for the absolute age of the Jurassic-Cretaceous boundary.
\end{abstract}

Supplementary material: Sample coordinates, values of the sandstone compositional framework and $\mathrm{U}-\mathrm{Pb}$ (LAM-MC-ICP-MS) age measurements of zircons grains are available at http://www. geolsoc.org.uk/SUP18718

Upper Jurassic continental sequences deposited on the southwestern proto-Pacific margin of Gondwana represent an important component of the Neuquén Basin between $31^{\circ}$ and $41^{\circ}$ South latitude in western central Argentina. These continental sediments are mainly grouped into the Tordillo Formation (Groeber 1946) and form one of the most characteristic lowstand wedges of the basin (Spalletti \& Veiga 2007; Veiga \& Spalletti 2007). This lowstand wedge is the main hydrocarbon reservoir and contains the largest conventional oil reserves in Argentina (Maretto et al. 2002). The Neuquén Basin is located in a retroarc setting (Vergani et al. 1995; Ramos 1999; Howell et al. 2005) where thousands of metres of marine and continental sediments were accumulated along the eastern side of the Andean volcanic arc from the Early Jurassic (Ramos
2010; and references therein) (Fig. 1a). Because of its retroarc position, important input from volcanic sources to the detrital sediments should be expected. However, the detrital input from the Andean arc was not constant. It varied over time and throughout the basin and was mixed with other pre-Andean volcanic materials. Previous analyses of sedimentary provenance in the Tordillo Formation were mainly based on petrographic and geochemical studies. These demonstrated the participation of the volcanic supply, but were not able to identify the ages of the sources (Marchese 1971; Gulisano 1988; Eppinger \& Rosenfeld 1996; Spalletti et al. 2008). Systematic studies based on sedimentary provenance in the Neuquén Basin, including U$\mathrm{Pb}$ zircon dating, remain scarce (Tunik et al. 2010; Naipauer et al. 2012; Di Giulio et al. 2012). 


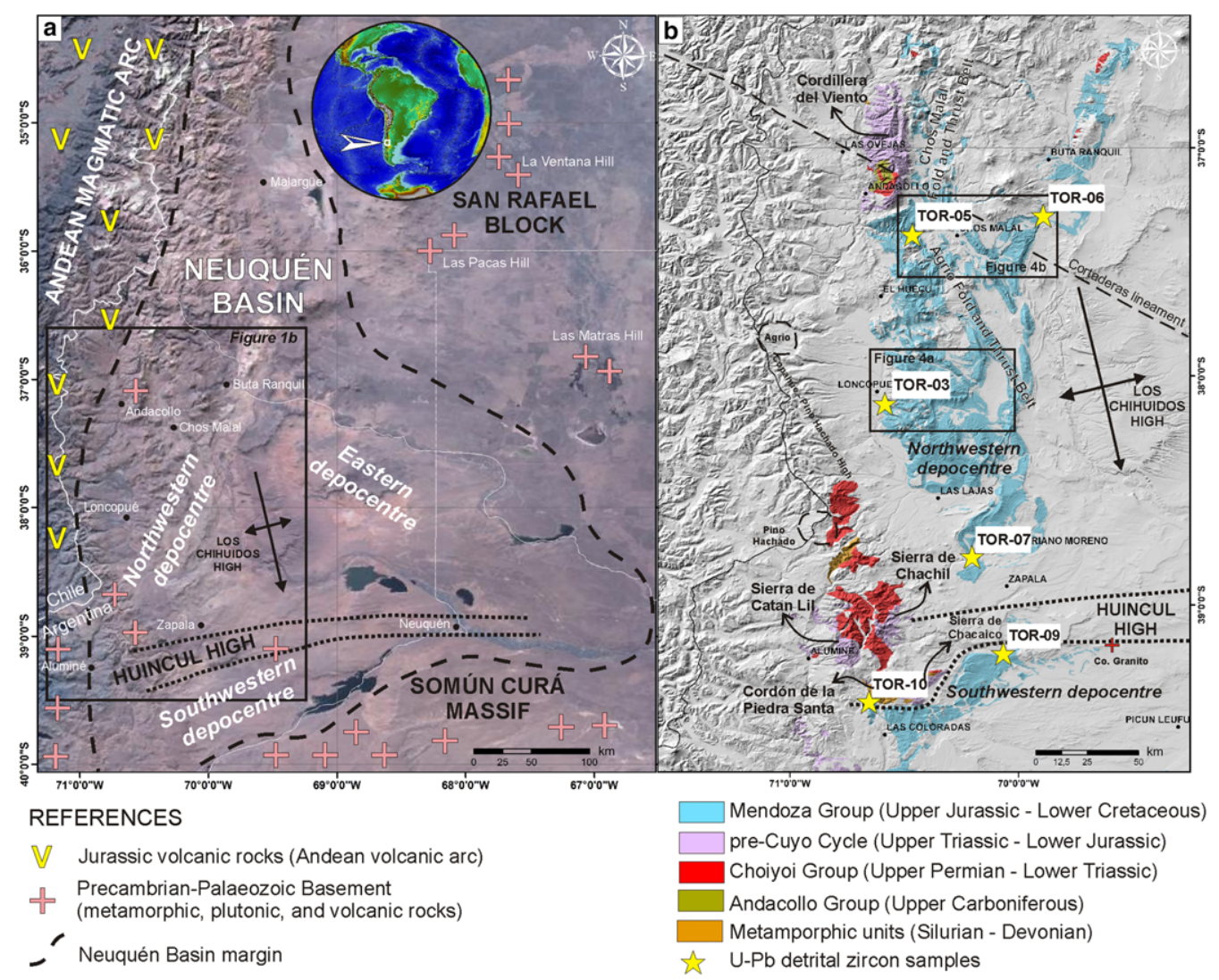

Fig. 1. (a) Sketch map of the Neuquén Basin showing its depocentres and the main tectonic elements for the Late Jurassic (based on Spalletti \& Colombo Piñol 2005). (b) Geological map with distribution of the outcrops of the Mendoza Group (Late Jurassic-Early Cretaceous) and the main pre-Middle Jurassic basement rocks. Sample localities for $\mathrm{U}-\mathrm{Pb}$ work for the Tordillo Formation are also shown.

The present study presents new $\mathrm{U}-\mathrm{Pb}$ data (LAM-MC-ICP-MS; Laser Ablation MicroprobeMulti-Collector-Inductively Coupled Plasma-Mass Spectrometer) on detrital zircons from outcrops of the northwestern region of the retroarc Neuquén Basin with a view to defining the age of the sediment sources. We investigate how the provenance patterns along a north-south transect through the western margin of the basin differ. The new data permit a more precise assessment of the maximum age of deposition of the Tordillo Formation and the description of regional and temporal changes in the sedimentary provenance. We also compare the pattern of detrital zircon ages obtained in this study with those obtained previously by Tunik et al. (2010) in a lowstand wedge developed in the Early Cretaceous within the Agrio Formation. The absence of provenance from the Andean arc is remarkable in this lowstand wedge. We therefore describe and discuss a major change in the palaeogeography and tectonic evolution between these lowstands within the Neuquén Basin, which is important in order to understand the mechanics of subsidence and the sedimentation control in a typical Andean retroarc basin. Finally, we discuss the maximum depositional age obtained in the Upper Jurassic succession and its relationship to the absolute age of the Jurassic-Cretaceous boundary.

\section{Geological and stratigraphic framework}

The geological history of the Neuquén Basin is intimately linked to the evolution of the southern Central Andes and was mainly affected by (1) changes in tectonic conditions of the protoPacific margin, (2) the installation of the Jurassic magmatic arc, and (3) eustatic global sea-level changes (Legarreta \& Gulisano 1989; Legarreta \& Uliana 1991; Vergani et al. 1995; Ramos 1999; Howell et al. 2005; Mpodozis \& Ramos 2008). 
Additionally, it is important to point out the tectonic control exerted by the structural fabrics of the Palaeozoic basement (Franzese \& Spalletti 2001). Although poorly exposed, this basement largely conditioned the evolution of the southern region of the basin, especially along the Huincul deformation zone (Vergani et al. 1995; Mosquera \& Ramos 2006; Mpodozis \& Ramos 2008; Ramos et al. 2011; Naipauer et al. 2012) (Fig. 1a, b).

The basement of the basin is composed of three main components (Fig. 2): (1) low- to highgrade metamorphic rocks of the Early Palaeozoic (Piedra Santa, Guaraco Norte, and Colohuincul formations; Cingolani et al. 2011, and references therein); (2) volcanic and volcaniclastic rocks with marine sediments of the Late Carboniferous (Andacollo Group; Llambías et al. 2007), and (3) plutonic and volcanic rocks grouped into the Upper Palaeozoic to Lower Triassic Choiyoi Group (Llambías $\&$ Sato 2011, and references therein). These basement components are mainly exposed in the Cordillera del Viento range, NW of the basin and in the western portion of the Huincul High in the Sierra de Chachil, Sierra de Chacaico, and Cordon de la Piedra Santa, south of the basin (see Fig. 1b). The Andacollo Group is only exposed on the western side of the Cordillera del Viento range (Fig. 1b). The basement was exhumed and eroded during the Early Triassic extension prior to the beginning of the filling of the Neuquén Basin; this extension phase produced a regional erosion surface on which the volcanic units of the Late Triassic and Early Jurassic were later deposited (Llambías et al. 2007).

During the complex tectonic evolution of the basin, three main stages are identified, which are also recognized in the stratigraphy (Fig. 2): the first Late Triassic-Early Jurassic rift stage is seen in the pre-Cuyo Cycle (e.g. Nireco, Lapa, Cordillera del Viento, and Remoredo formations; Gulisano 1981; Franzese \& Spalletti 2001; Schiuma \& Llambías 2008; Carbone et al. 2011), followed by a long period of thermal sag (Mid Jurassic to Early Cretaceous) comprising the Cuyo, Lotena, Mendoza and Bajada del Agrio groups and finally a Late Cretaceous-Cenozoic foreland stage being included in the Neuquén and Malargüe groups (Gulisano et al. 1984; Vergani et al. 1995; Franzese \& Spalletti 2001; Howell et al. 2005). This last stage coincides with the beginning of the compressive Andean deformation at these latitudes (Tunik et al. 2010, and references therein).

The stratigraphy of the Neuquén Basin is complex, not only because of its large regional extension but also because of the diversity of local names. A summary of the general stratigraphy, tectonic evolution, biostratigraphic resolution and available $\mathrm{U}-\mathrm{Pb}$ absolute ages is shown in Figure 2. As shown there, good biostratigraphic control is well documented in many units of the Cuyo, Lotena and Mendoza groups. However, it highlights the low geochronological control that exists throughout the whole stratigraphic column (Fig. 2).

The Mendoza Group (Stipanicic et al. 1968) represents a sedimentary cycle developed during the sag phase (Howell et al. 2005). Sedimentation started with typical continental red facies (Tordillo Formation), which are the subject of this study. These sediments are covered by marine dark shales and limestones of the Vaca Muerta Formation (Weaver 1931), which represent a widespread marine transgression, well documented by ammonite faunas throughout the entire basin (Leanza 1981; Gulisano \& Gutiérrez Pleimling 1995; Vergani et al. 1995; Riccardi 2008a, b). Finally, mixed continental and marine facies are increasingly restricted and are included in the Mulichinco and Agrio formations (Weaver 1931).

The base of the Mendoza Group is assigned to the Kimmeridgian due to the stratigraphic position of the Tordillo Formation (Fig. 2). This unit unconformably overlies the Lotena Group (Leanza 1992). In this group the La Manga Formation (Stipanicic 1966) is characterized by its poor ammonoid fauna of mid Oxfordian age (Stipanicic 1951; Riccardi 1984, 2008a, b). Below the Lotena Group, the Cuyo Group was developed (see Fig. 2). It is important to point out that, in the eastern sector of the Cordillera del Viento (Fig. 1b), a tuff layer intercalated in the Chacay Melehue Formation, at the top of the Cuyo Group, yielded the ID-TIMS (Isotope Dilution-Thermal Ionization Mass Spectrometry) zircon age of $164.6 \pm 0.2 \mathrm{Ma}$ (Kamo \& Riccardi 2009). This absolute age is in agreement with well-documented ammonoid fauna present in the sequence, coinciding with the BathonianCallovian boundary (late Mid Jurassic) (Kamo \& Riccardi 2009) (Fig. 2).

The age of the top of the Mendoza Group is well constrained through the study of the upper Agrio Formation. The fossiliferous content of this unit indicates a late Hauterivian age, which was corroborated by a $\mathrm{U}-\mathrm{Pb}$ absolute zircon age (SHRIMP) at c. $132 \mathrm{Ma}$ (Aguirre-Urreta et al. 2008). The zircons analysed correspond to a tuff layer in the Agua de la Mula Member, extending the age of the Mendoza Group to the early Barremian (Early Cretaceous) (Aguirre-Urreta et al. 2008; Aguirre-Urreta \& Rawson 2012) (Fig. 2).

\section{The Tordillo Formation and its equivalents}

Previous studies on the Tordillo Formation focused on its lithological composition and stratigraphic relationships (Groeber 1946; Stipanicic 1966), as well as on its main sedimentological aspects 


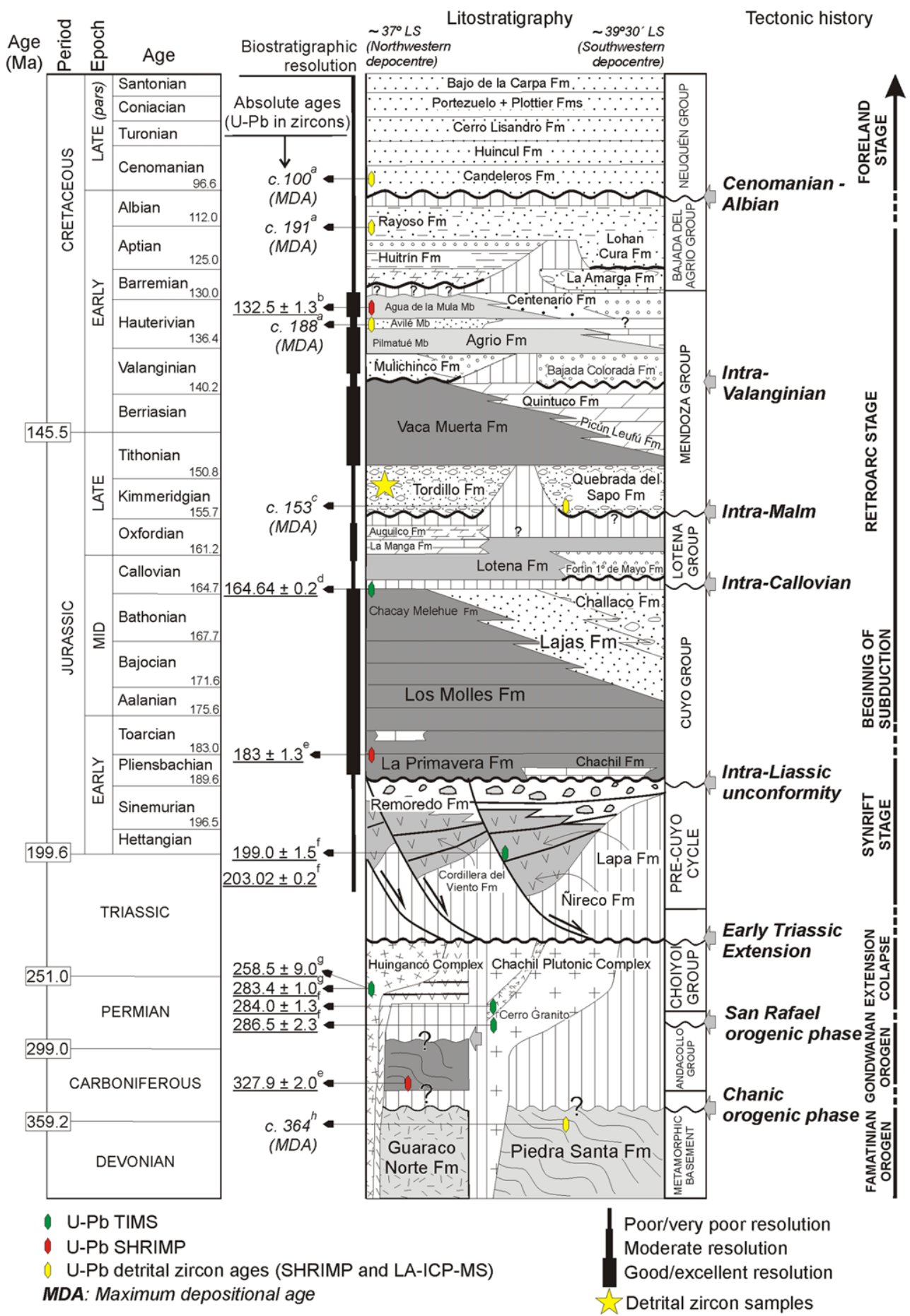

Fig. 2. Tectonostratigraphic chart of the Neuquén Basin (modified from Howell et al. 2005). The table shows the chronostratigraphy, U-Pb zircon ages (a, Tunik et al. 2010; b, Aguirre-Urreta et al. 2008; c, Naipauer et al. 2012; d, Kamo \& Riccardi 2009; e, Suárez et al. 2008; f, Schiuma \& Llambías 2008; g, Sato et al. 2008; h, Ramos et al. 2010), biostratigraphic resolution, lithostratigraphic, tectonic setting and stratigraphic location of the studied samples. 
(Marchese 1971; Legarreta \& Gulisano 1989; Legarreta \& Uliana 1999; Zavala et al. 2005; Spalletti \& Colombo Piñol 2005; Veiga \& Spalletti 2007; Spalletti et al. 2008, 2011; López-Gómez et al. 2009). Rocks of equivalent age exposed along the Main Cordillera of Argentina and Chile from nearly $31^{\circ} \mathrm{S}$ to $37^{\circ} \mathrm{S}$ are known as the Rio Damas Formation (Vicente 2005, 2006; Charrier et al. 2007). South of $37^{\circ} \mathrm{S}$, where the outcrops extend eastward and become part of the Neuquén Embayment up to $c .41^{\circ} \mathrm{S}$ (Fig. 1a) the Tordillo Formation is composed of conglomerates, sandstones, shales and tuffs (Fig. 3). In the southern and western areas of the basin, coarse facies including conglomerates and sandstones are dominant, while in the northern and eastern parts distal facies predominate, where pelites, siltstones and tuffs are common (Marchese 1971). Thickness is also variable within the basin, where three main depocentres have been commonly identified (Spalletti \& Colombo Piñol 2005; Spalletti \& Veiga 2007) (Fig. 1a). The northwestern and eastern depocentres (Spalletti \& Colombo Piñol 2005) are located north of the Huincul High and separated by the Los Chihuidos High (Ramos 1978) (Fig. 1a). The Tordillo Formation is mostly known from outcrops of the northwestern depocentre, whereas in the subsurface of the Neuquén Embayment, the rocks of the eastern depocentre are known as the Sierras Blancas and Catriel formations (Digregorio 1972; Spalletti \& Veiga 2007; Spalletti et al. 2011). South of the Huincul High the Kimmeridgian deposits are located in a southwestern depocentre and correspond to the Quebrada del Sapo Formation (Zavala et al. 2005; Spalletti \& Veiga 2007) (Fig. 1a). The maximum thickness is up to $900 \mathrm{~m}$ in the northwestern depocentre, decreasing considerably towards the east to $90 \mathrm{~m}$ on the edge of the Los Chihuidos High, while south of the Huincul High the thickness is less than $100 \mathrm{~m}$ (Marchese 1971; Spalletti \& Veiga 2007; Spalletti et al. 2011).

The Tordillo Formation and equivalent units display highly variable depositional systems in the three different depocentres (Marchese 1971; Gulisano 1988; Legarreta \& Gulisano 1989; Legarreta \& Uliana 1999; Spalletti \& Colombo Piñol 2005; Spalletti \& Veiga 2007). Ephemeral fluvial systems and playa lakes are the main deposits in the north (Spalletti \& Colombo Piñol 2005; Spalletti \& Veiga 2007) (Fig. 3a-e). Particularly at the top of the Río Neuquén and Loncopué sections, primary deposits of tuff and volcaniclastic rocks are present (Spalletti \& Colombo Piñol 2005) (Fig. 3f). Proximal alluvial fan and fluvial deposits are dominant in the southern sector of the northwestern depocentre, for example the Río Covunco section (Fig. 3g). In the southwestern and eastern depocentres, the depositional systems are characterized by the transition from ephemeral fluvial to aeolian systems (Gulisano 1988; Zavala et al. 2005; Veiga \& Spalletti 2007) (Fig. 3h).

The Kimmeridgian to earliest Tithonian age of these deposits was historically constrained by their stratigraphic position due to the lack of fossils with biostratigraphic value and radiometric dates. They rest on an angular unconformity with the Lotena Group (Callovian-Oxfordian) and are concordant with, and transitional to, the Vaca Muerta Formation. The age of the latter is late Early Tithonian to Early Valanginian based on its ammonite faunas (Leanza 1981; Aguirre-Urreta \& Rawson 1999). The first U-Pb absolute ages on detrital zircons of the Tordillo and Quebrada del Sapo formations showed that the maximum age of deposition is c. $153 \mathrm{Ma}$ (Kimmeridgian), at least for the proximal fluvial facies from the southern sector of the basin (Naipauer et al. 2012). These authors mentioned, however, that it is noteworthy that in all samples analysed a significant number of detrital zircon ages (c. $145 \mathrm{Ma}$ ) are younger than the currently accepted age for the Kimmeridgian/ Tithonian boundary.

\section{Provenance data background}

The Neuquén Basin is bounded to the NE and SW by the San Rafael Block and the Somún Curá Massif, respectively, and its western margin is defined by an almost continuous Andean volcanic arc (Digregorio et al. 1984) (Fig. 1a). Previous provenance studies in the Tordillo Formation concluded that the main source of sediment supply comprised basic to acid volcanic rocks (Marchese 1971; Gulisano 1988; Mescua et al. 2008; Spalletti et al. 2008). Gulisano (1988) was the first to suggest that the source area of clastic, pyroclastic and volcanic material was the Andean magmatic arc. Direct evidence of the activity of this arc is observed in the Rio Damas Formation, where andesitic volcanic rocks are interlayered in the clastic sequence (Charrier et al. 2007). The petrographic and geochemical studies agree with an Andean arc source, but provenance from basement acid volcanics of the Choiyoi Group was also identified (Mescua et al. 2008; Spalletti et al. 2008).

As well as the significant volcanic component, igneous-metamorphic rocks are also represented in a lesser proportion. $\mathrm{U}-\mathrm{Pb}$ ages on detrital zircons, separated from conglomerates from the southern region of the basin, indicate a dominant contribution from the Andean Jurassic arc with ages between $c$. 178 and $153 \mathrm{Ma}$ and from synrift Late Triassic volcanism between 220-200 Ma. They also show an input from Upper Permian (280-260 Ma) and Upper Devonian (c. $360 \mathrm{Ma}$ ) 


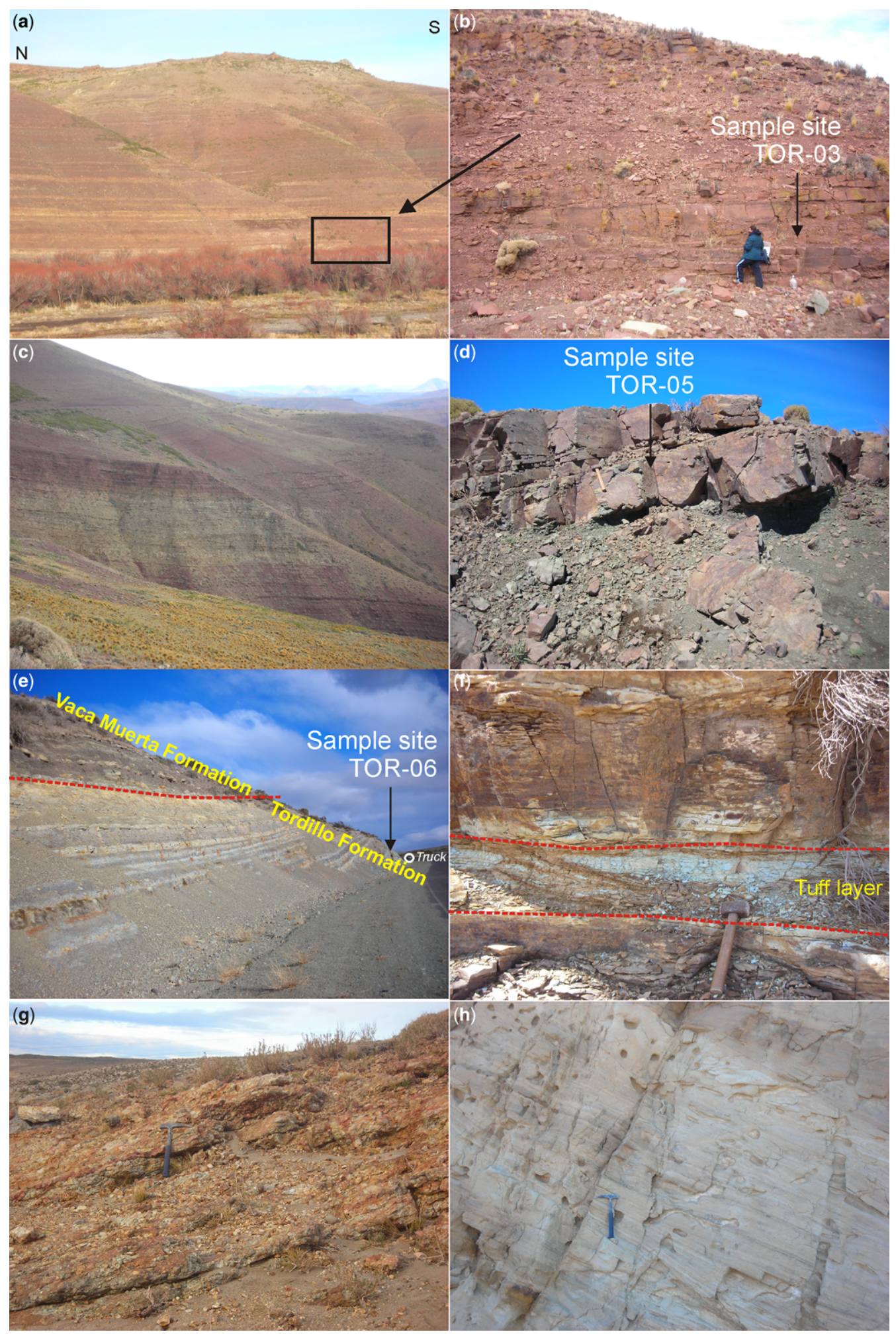


sources of igneous-metamorphic basement (Naipauer et al. 2012).

\section{Samples and analytical methods}

The analysed samples were taken from different localities within the Tordillo Formation with wellknown stratigraphic control. The samples are distributed along the western part of the Neuquén Basin (Fig. 1b). The provenance analysis included detailed petrographic studies and zircon morphology analyses to define the main populations in conjunction with $\mathrm{U}-\mathrm{Pb}$ geochronological ages (LAM-MC-ICP-MS).

Petrographic studies were performed on samples of sandstone and conglomerate matrix from six classic profiles of the basin. Detailed stratigraphic columns and sedimentological aspects have been surveyed previously (see Gulisano 1988; Gulisano \& Gutiérrez Preimling 1995; Spalletti \& Colombo Piñol 2005; Zavala et al. 2005; Veiga \& Spalletti 2007; Spalletti \& Veiga 2007). The samples in the northwestern depocentre were taken from the classic sections: (1) Loncopué, TOR-01, TOR-02 and TOR-03; (2) Río Neuquén, TOR-04 and TOR-05; (3) Pampa Tril, TOR-06; and (4) Arroyo Covunco, TOR-07 (Fig. 1b). For the southwestern depocentre, the samples correspond to the following profiles: (5) Río Picún Leufú, TOR-08 and TOR-09 and (6) Fortín Primero de Mayo, TOR-10 (Fig. 1b). The sandstones were petrographically classified according to the diagram of Folk et al. (1970), and were also plotted in the provenance diagram of Dickinson et al. (1983). The petrography was also used to select samples for $\mathrm{U}-\mathrm{Pb}$ dating.

We analysed the U-Pb (LAM-MC-ICP-MS) ages of three samples (TOR-03, TOR-05 and TOR-06) of the Tordillo Formation from the northwestern depocentre. These results are compared with data from the southern region (samples TOR07, TOR-09 and TOR-10; Naipauer et al. 2012). The analysed samples correspond to a fine-grained red sandstone located at the base of the Loncopué profile (TOR-03; Fig. 4a), a fine-grained green volcaniclastic sandstone from the top of the Río Neuquén profile (TOR-05; Fig. 4b) and a green siltstone at the top the Pampa Tril profile (TOR-06;
Fig. 4b). The total results complete a set of ${ }^{237} \mathrm{U}-$ $\mathrm{Pb}$ concordant ages of detrital zircons.

For U-Pb LAM-MC-ICP-MS zircon analyses, $5 \mathrm{~kg}$ of each rock sample were crushed. They were then powdered and sieved to fractions between 75 and $212 \mu \mathrm{m}$. Heavy mineral concentrates were obtained by panning and were subsequently purified by an electromagnetic (Frantz) method to eliminate only the highly magnetic fraction. Zircon grains were selected and set in epoxy resin mounts. The mount surface was then polished to expose the grain interiors. Backscattered electron (BSE) images of zircons were obtained using an SEM (Scanning Electron Microscope) JEOL JSM 5800 at Universidade Federal do Rio Grande do Sul (UFRGS), Brazil. The U-Pb LAM-MC-ICPMS zircon analyses were carried out using a Finnigan Neptune coupled to a UP-213nm Nd-YAG laser ablation system (New Wave Research, USA) installed in the Isotope Geology Laboratory of the Geoscience Institute of UFRGS.

The analyses were performed as a single spot of $30 \mu \mathrm{m}$ using the following laser parameters: repetition rate of $10 \mathrm{~Hz}$, energy of $0.5-1.1 \mathrm{~mJ} \mathrm{~cm}^{-2}$, $40 \mathrm{~s}$ ablation time and $1 \mathrm{~s}$ integration time. Faraday cup configuration of the MC-ICP-MS was ${ }^{208} \mathrm{~Pb},{ }^{232} \mathrm{Th}$ and ${ }^{238} \mathrm{U}$, and ion counters on cup L4 with $2^{02} \mathrm{Hg},{ }^{204} \mathrm{~Pb},{ }^{206} \mathrm{~Pb}$ and ${ }^{207} \mathrm{~Pb}$. Main gas flow was $15 \mathrm{l} / \mathrm{min} \mathrm{Ar}$, auxiliary gas flow $0.81 \mathrm{~m}^{-1}$, while the sample was carried with $0.751 / \mathrm{min} \mathrm{Ar}$ plus $0.42 \mathrm{l} / \mathrm{min} \mathrm{He}$. Unknown analyses were bracketed for internal instrumental fractionation control and mass bias following the Albarede et al. (2004) method by measurements of the international standard GJ-1 (Jackson et al. 2004) and blanks at every set of four zircon spots.

The raw data were reduced using an Excel worksheet (Buhn et al. 2009). The ${ }^{206} \mathrm{~Pb}-{ }^{238} \mathrm{U}$ ratio was recalculated using the linear regression method of Košler et al. (2002) when laser fractionation correction was necessary. The ${ }^{204} \mathrm{~Pb}$ (common lead) interference and background was observed using ${ }^{202} \mathrm{Hg}$ and $\left({ }^{204} \mathrm{Hg}+{ }^{204} \mathrm{~Pb}\right)$ masses during analyses. The analysed grains have low common lead, and the usual ${ }^{204} \mathrm{~Pb}$ correction using the Stacey \& Kramers (1975) model was not necessary. Corrected ${ }^{206} \mathrm{~Pb} /{ }^{207} \mathrm{~Pb}$ and ${ }^{206} \mathrm{~Pb}-{ }^{238} \mathrm{U}$ ratios were shifted into absolute age data using ISOPLOT/Ex (Ludwig 2003). The probability

Fig. 3. (a-g) Photographs of the Tordillo Formation, some of which are the localities of the U-Pb samples. (a, b) Red fluvial deposits at Loncopué, a fine red sandstone located at the base of the profile was sampled from $\mathrm{U}-\mathrm{Pb}$ analysis (sample TOR-03). (c, d) Overview of the deposits and the fine green volcaniclastic sandstone from the top of the Río Neuquén profile (TOR-05). (e, f) View in detail of the transitional contact between Tordillo and Vaca Muerta formations in the Pampa Tril area; see the sample locality at the top the Pampa Tril profile (sample TOR-6). (g) Fine-grained conglomerate and sandstone levels at the Arroyo Covunco locality (sample TOR-07). (h) Aeolian deposits of the Quebrada del Sapo Formation at Arroyo Picún Leufú, southwestern depocentre. 

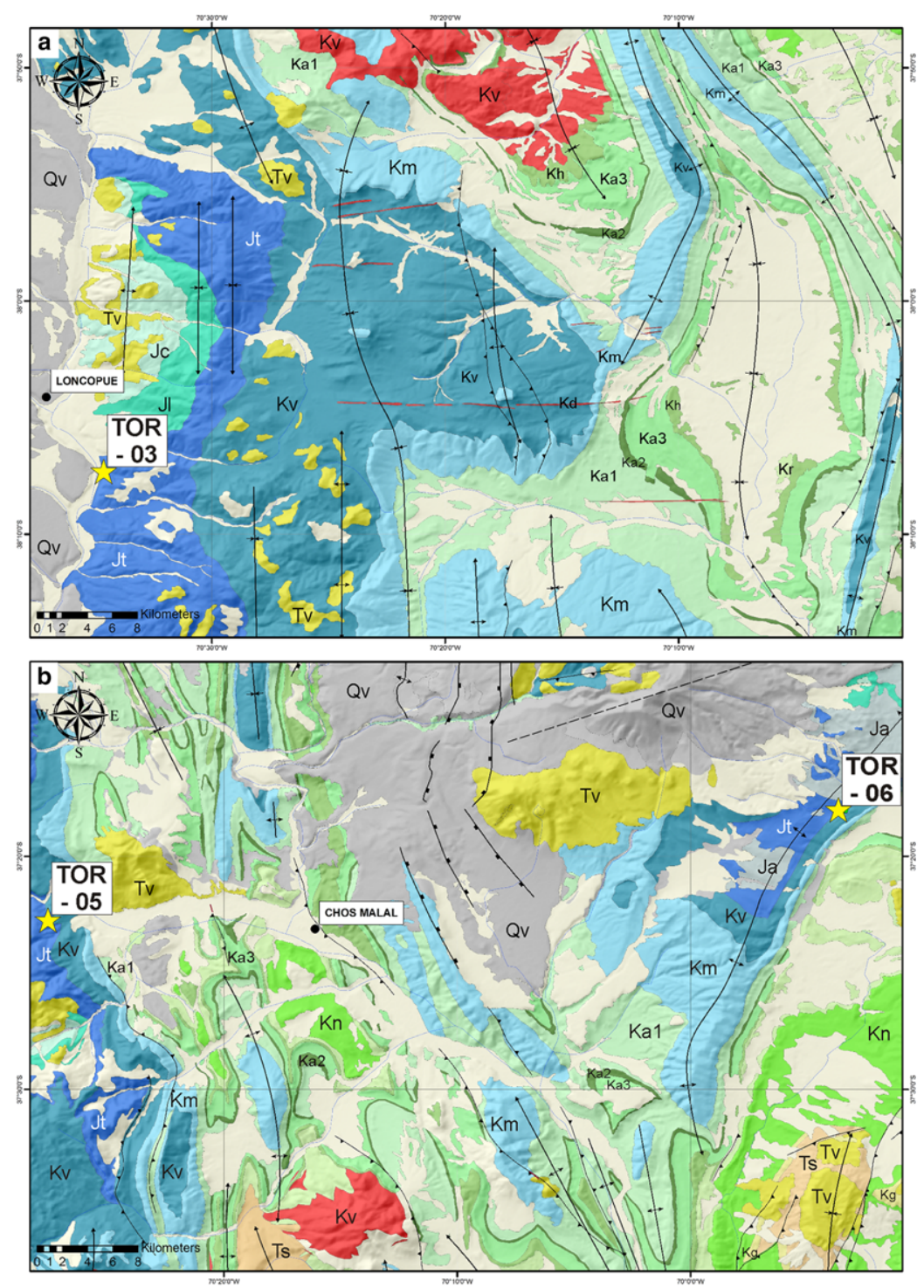

\section{References}

\begin{tabular}{|c|c|c|c|c|c|}
\hline \multicolumn{3}{|c|}{ 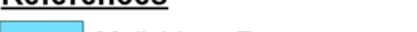 } & \multirow{2}{*}{ Co. Mocho Dyke } & \multirow[b]{2}{*}{ Qv } & \multirow[b]{2}{*}{ Quaternary volcanics } \\
\hline $\mathrm{Km}$ & Mulichinco Fm. & 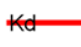 & & & \\
\hline Kv & Vaca Muerta Fm. & $\mathrm{Kr}$ & Rayoso Fm. & Tv & Neogene volcanics \\
\hline $\mathrm{Jt}$ & Tordillo Fm. & Kh & Huitrin Fm. & Ts & Neogene sediments \\
\hline $\mathrm{Ja}$ & Auquilco $\mathrm{Fm}$. & Ka3 & Upper Agrio Fm. & $\mathrm{Kg}$ & Malargüe Gp. \\
\hline J & Lotena Gp. & $\mathrm{Ka} 2$ & $\begin{array}{l}\text { Avile Member } \\
\text { (Agrio Fm.) }\end{array}$ & Kv & Naunauco Gp. \\
\hline $\mathrm{Jc}$ & Cuyo Gp. & Ka1 & Lower Agrio Fm. & $\mathrm{Kn}$ & Neuquén Gp. \\
\hline
\end{tabular}

Fig. 4. Geological map with sample locations of the Tordillo Formation. Detail of geology of (a) the Loncopué region (Cerro Mocho) and (b) the Chos Malal region. 
diagrams were constructed using the same software. The reported errors were propagated by quadratic addition of external reproducibility and within-run precision.

\section{Results}

\section{Sandstone petrography provenance}

The samples were studied under a polarized microscope and classified following the scheme of Dott (1964) separating sandstones and wackes (TOR-01 and TOR-06). The sandstones are poorly sorted and most of the detrital fragments are sub-angulose, although some subrounded clasts are also identified (Fig. 5). There are shards and pumice fragments immersed in a carbonate cement (TOR-02; Fig. 5b). Other types of cements are argillaceous and zeolitic.

The Gazzi-Dickinson method was used for the provenance studies as suggested by Zuffa (1985). Some samples were discarded due to their fine grain size (TOR-02, TOR-04 and TOR-08). Depending on the size of the thin section, 400 or 500 points were counted. The five analysed samples were classified as lithoarenite $(n=1)$ Q15F14L71 and feldspatic lithoarenites $(n=4)$ Q20F30L50 after Folk et al. (1970) (Fig. 6).

The sandstones are classified in order of abundance of lithic fragments, feldspar and quartz. The monocrystalline quartz (Fig. 5c) is more abundant than the polycrystalline in samples TOR-03, TOR-05 and TOR-07. In samples TOR-09 and TOR-10 the relation is reversed; the polycrystalline quartz is more abundant than the monocrystalline. The relative abundances of plagioclase and $\mathrm{K}$-feldspar are variable. In general, plagioclase is more abundant, but in sample TOR-09 the relationship is inverted. This can be explained by the large amount of plutonic rock fragments and metamorphic lithic fragments (Fig. 5a).

The analyses of the rock fragments indicate that volcanic rocks are dominant (Fig. 5e). However, the composition of the rock fragments in the southwestern and northwestern depocentres is quite different. In the $\mathrm{SW}$, the plutonic and metamorphic rock fragments (Fig. 5c) are remarkable, whereas in the $\mathrm{NW}$, sedimentary rock and angular quartz fragments are abundant (Fig. 5d). The presence of altered lithic fragments (Fig. 5f) and pseudomatrix is common in the northwestern samples and absent or very rare in the samples from the SW.

\section{Zircon morphology analysis}

The zircons were separated by conventional techniques and their external morphologies were studied under a binocular microscope. For each sample, the main zircon populations were recognized and described according to their shape, colour, size, inclusions and fractures.

Sample TOR-03. The zircon crystals belong to the size fraction of $<150 \mu \mathrm{m}$. The predominant morphological features are prismatic habit and subrounded to subidiomorphic form (P1). Many crystals are characterized by their elongation $(>5: 1)$ and represent c. $20 \%$ of the total grains (P2). They are mostly transparent or have a yellow colour. A third population (P3) is represented by a few crystals that have rounded form. In general, the zircons investigated have few inclusions and fractures (Fig. 7a).

Sample TOR-06. The small numbers of grains separated are smaller than $100 \mu \mathrm{m}$. The largest population of zircons (P1) is characterized by crystals with short prismatic habit, although some zircon grains forming long prisms (P2) are also present. The forms are subrounded and subidiomorphic, although a few crystals have idiomorphic form and some of them present bipyramidal crystal forms. They are transparent and have some inclusions. Some less abundant crystals are rounded (P3) (Fig. 7b).

Sample TOR-05. Two groups of zircons with different sizes are recognized. Crystals forming population P1 are the most abundant grains and are smaller than $100 \mu \mathrm{m}$, with short prismatic habit (elongation $<3: 1$ ) and subrounded to rounded form. Few crystals were observed with subidiomorphic forms. They are mostly transparent. Some are yellow in colour, with inclusions, and many are broken. The second group (P2) is characterized by grain size larger than $200 \mu \mathrm{m}$; the crystals have subrounded to subidiomorphic form. Some have a short prismatic habit, but others have a long prismatic habit and are broken. They are mostly transparent and there are some grains with a pink colour. Inclusions were observed in several grains (Fig. 7c).

\section{$U-P b$ data}

The $\mathrm{U}-\mathrm{Pb}$ geochronological analysis of detrital zircon grains is a powerful tool with which to obtain valuable information on the provenance and maximum age of sedimentary deposition (Mueller et al. 1994; Morton \& Hallsworth 1999; Fedo et al. 2003; Bahlburg et al. 2009; Dickinson \& Gehrels 2009; Bahlburg et al. 2010). A fraction of zircon crystals were randomly separated and mounted in epoxy sections. The minerals were then analysed using the $\mathrm{U}-\mathrm{Pb}$ method (LAM-MCICP-MS) to obtain absolute ages.

In sample TOR-03, a total of 44 zircon grains were analysed, but eight analyses were rejected because of high discordance (Fig. 8a). The spectra 

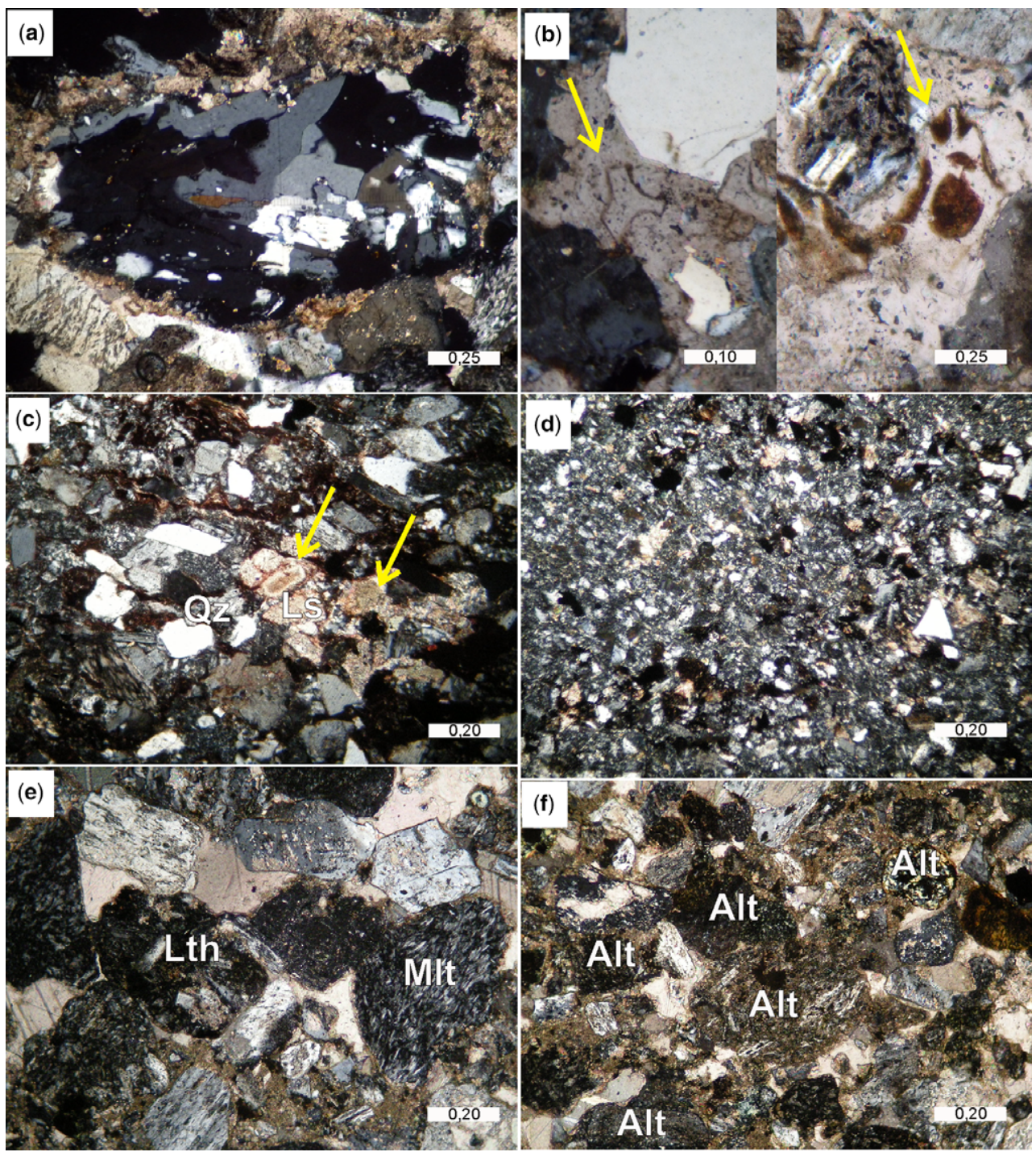

Fig. 5. Photomicrographs of the Tordillo Formation. (a) Metamorphic lithic fragments are common in the base of the column (sample TOR-02, Loncopué section). (b) Cuspate and pumice shards (arrows) provide evidence of active volcanism during sedimentation (sample TOR-02). (c) Monocrystalline quartz (Qz) and sedimentary lithic fragments (Ls and arrows) distinguish the samples from the northern depocentre from those of the southern depocentres. The southern samples are characterized by the presence of polycrystalline quartz and plutonic lithic fragments (see fig. 8c in Naipauer et al. 2012) (sample TOR-09, Picún Leufú section). (d) Angular quartz on the sublithic wacke (Dott 1964) suggests a volcanic provenance (sample TOR-06, Pampa Tril section). (e) Microlithic (Mlt) and lathwork textures (Lth) of volcanic lithic fragments suggest the provenance from the Jurassic volcanic arc, clearly different from the provenance from the Choiyoi volcanics (see fig. 8d in Naipauer et al. 2012) (sample TOR-05, Río Neuquén section). (f) The presence of altered lithic fragments (Alt) is remarkable; much of them are probably of volcanic and sedimentary origin (sample TOR-05, Río Neuquén section).

of the 36 concordant ages are between $145 \mathrm{Ma}$ and $777 \mathrm{Ma}$. The distribution of the ages is characterized by multimodal maximum peaks at $c .145, c .160$, c. 191, c. 207 and c. 280 Ma. There are two isolated ages at $c .684 \mathrm{Ma}$ and $c .777 \mathrm{Ma}$ (Fig. 9a). The inset of Figure 9a shows some BSE images of the most typical detrital zircon populations from sample TOR-03. 


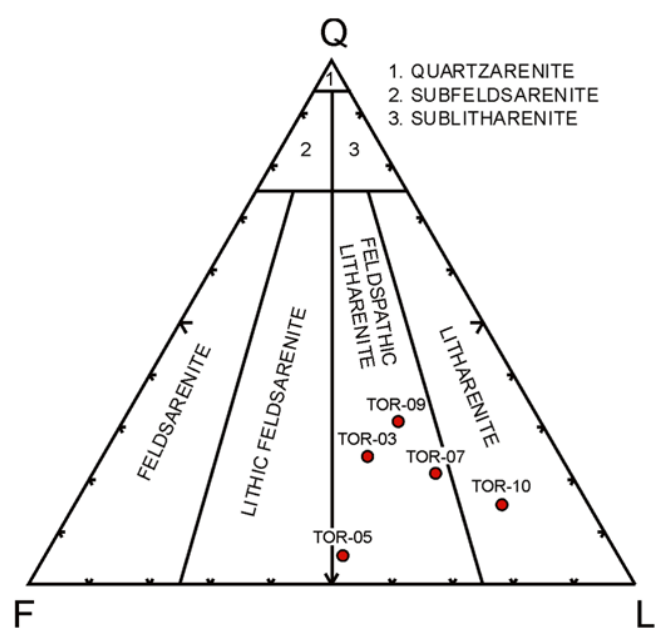

Fig. 6. Sandstone classification based on the scheme of Folk et al. (1970).

A total of 36 ages were obtained from sample TOR-06, but two grains were rejected, one because of high discordance and another for its high uncertainty (Fig. 8c). The concordant ages plot between 142 and $2114 \mathrm{Ma}$ but most of the ages are Late Jurassic to Early Carboniferous. The curve of relative probability shows several maximum peaks at c. $143, c .153, c .170$ and $c$. $268 \mathrm{Ma}$, plus isolated ages at $c .334, c .348$ and $c$. $2114 \mathrm{Ma}$ (Fig. 9b). Some BSE images of the detrital zircons analysed are included in Figure 9b; these show the internal structure, which is characterized by oscillatory zoning that indicates a magmatic origin for these grains. The idiomorphic form and prismatic shape of the crystals may suggest a volcanic origin.

Sample TOR-05 had 36 zircons analysed, five of which were rejected due to high discordance (Fig. 8e) and another due to the high uncertainty. The remaining grains yielded 30 concordant ages in the relatively narrow interval between 138 and $213 \mathrm{Ma}$, producing a unimodal distribution (Fig. 9c). The most important maximum peak occurs at c. $144 \mathrm{Ma}$, although there are also minor peaks at c. $170 \mathrm{Ma}$ and a single age at $c .213 \mathrm{Ma}$ (Fig. 9c). The BSE images of the zircon grains (inset in Fig. 9c) show faint internal structures, but oscillatory zoning can be recognized, so a magmatic origin is also postulated for these grains.

\section{Integration of the data and discussion}

\section{Source regions along the Neuquén Basin}

The source regions defined by the provenance analysis are in accordance with the sediment transport directions as shown by palaeocurrent studies in the basin. These are characterized by axial systems parallel to the Andean chain with north to NE trends (Gulisano 1988; Spalletti \& Colombo 2005; Spalletti et al. 2008). The petrographic provenance studies using the Dickinson et al. (1983) diagrams indicate that all samples belong to the arc fields (Fig. 10a, b), which is not surprising considering that the Tordillo Formation was deposited near the Andean arc in a retroarc position. However, they could also have received sediments from the pre-Cuyo Cycle volcanism and from the Choiyoi magmatic rocks, as mentioned by Spalletti et al. (2008). The zircon morphology and internal textures also indicate a magmatic origin for the main detrital zircons for the northwestern depocentre. The dominance of prismatic and long prismatic crystal habits (elongation 5:1) suggests a volcanic origin for these zircons (P1 and P2). The absence of zircon populations characterized by idiomorphic, multifaceted and pink coloured grains in the northwestern depocentre is remarkable; these kinds of grains are present in samples from the southern part of the basin and were probably derived from basement areas (Naipauer et al. 2012).

The summary $\mathrm{U}-\mathrm{Pb}$ age probability curve for all six analysed samples indicates that the most important source of sediments was the Jurassic Andean magmatic arc (Fig. 11). The maximum peaks of zircon ages at c. 144, c. 153 and $c$. $178 \mathrm{Ma}$ coincide with the main magmatic pulses in the Andean arc (Castro et al. 2011, and references therein). Also, two secondary source regions are defined according to the maximum frequency peaks at c. $218 \mathrm{Ma}$ and c. $275 \mathrm{Ma}$ (Fig. 11). The younger peaks are consistent with the ages of synrift volcanism represented in the pre-Cuyo Cycle, which has ages varying between $c .182$ and $c .219 \mathrm{Ma}$ (Rapela et al. 1983; Pángaro et al. 2002; Franzese et al. 2006; Schiuma \& Llambías 2008). Rocks with these ages are well exposed along the Huincul High and in the Cordillera del Viento. The Late Palaeozoic peaks are consistent with the c. 258 and c. 286 Ma Choiyoi magmatic province (Llambías \& Sato 2011, and references therein). These rocks form the core of large basement anticlines in the Huincul High and the Cordillera del Viento, but they are also exposed in the San Rafael Block, in the northeastern margin of the basin (Fig. 1a, b). The smaller amount of ages from the Early Palaeozoic and many minor Precambrian ages might represent evidence of metamorphic basement sources at the western margin of the basin (Fig. 1b). In the southern part, this basement is extensively exposed and corresponds to the Piedra Santa Formation (Franzese 1995) with detrital zircon ages of c. $364 \mathrm{Ma}$ (Ramos et al. 2010). Alternatively, the Colohuincul Complex may also be mentioned 


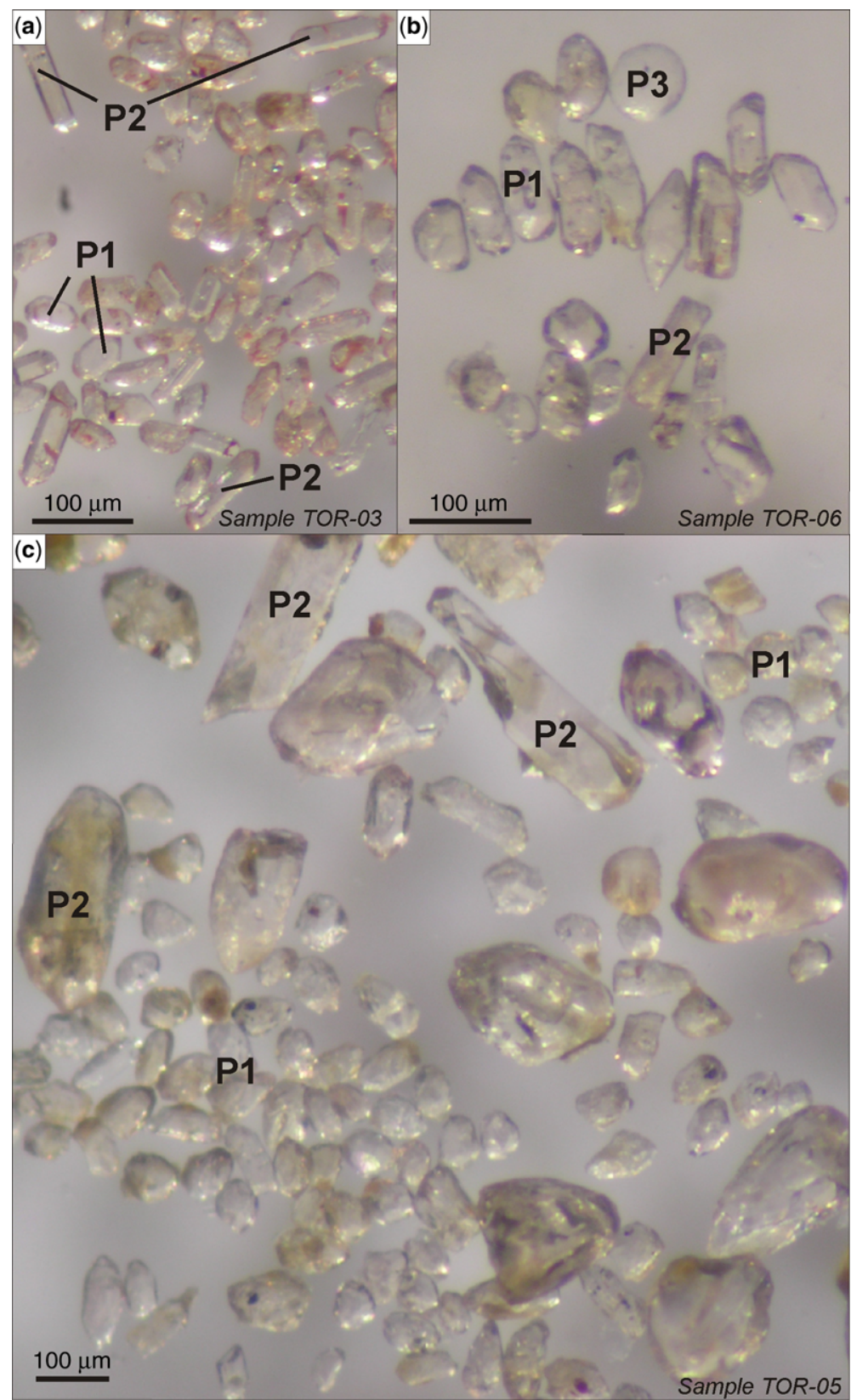

Fig. 7. Stereo microscope images of the zircons in the studied samples: (a) TOR-03, (b) TOR-06 and (c) TOR-05.

(Lucassen et al. 2004). To the north, in the Cordillera del Viento, there is also a small outcrop of metamorphic basement known as the Guaraco Norte Formation (Zappettini et al. 1987) that could have acted as a source region at this latitude (Figs 1b \& 2). Further outcrops of the metamorphic basements grouped in the Huechulaufquen Formations are discontinuously exposed along the Patagonian Cordillera (Pankhurst et al. 2006; Ramos 2008).

To the SE of the basin, Palaeozoic, Triassic and Lower Jurassic magmatic rocks are widely 

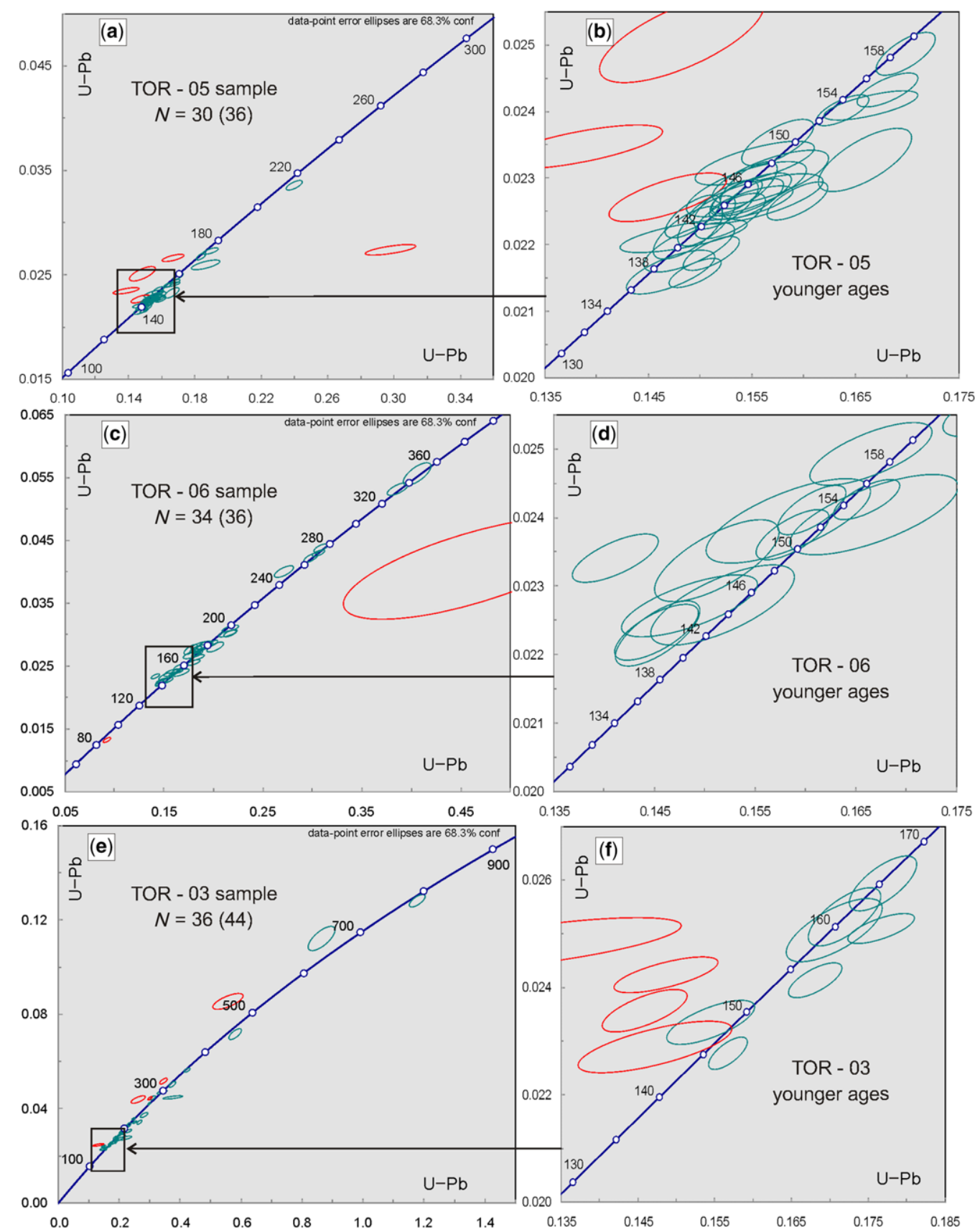

Fig. 8. U-Pb concordia plots: $(\mathbf{a}, \mathbf{b})$ TOR-05, $(\mathbf{c}, \mathbf{d})$ TOR-06, $(\mathbf{e}, \mathbf{f})$ TOR-03. The detrital zircon ages shown in the concordia plots are the concordant ages (in green) and discordant ages (in red) discussed in the text. For interpretation of the references to colour in this figure legend, the reader is referred to the web version of this article.

exposed in the Somún Curá Massif (Cingolani et al. 1991; Rapela et al. 1991, 2005; Varela et al. 2005; Pankhurst et al. 2006) (Fig. 1a). Several authors have interpreted that the detrital influx in the southwestern depocentre was supplied by this region (Spalletti \& Veiga 2007; Veiga \& Spalletti 

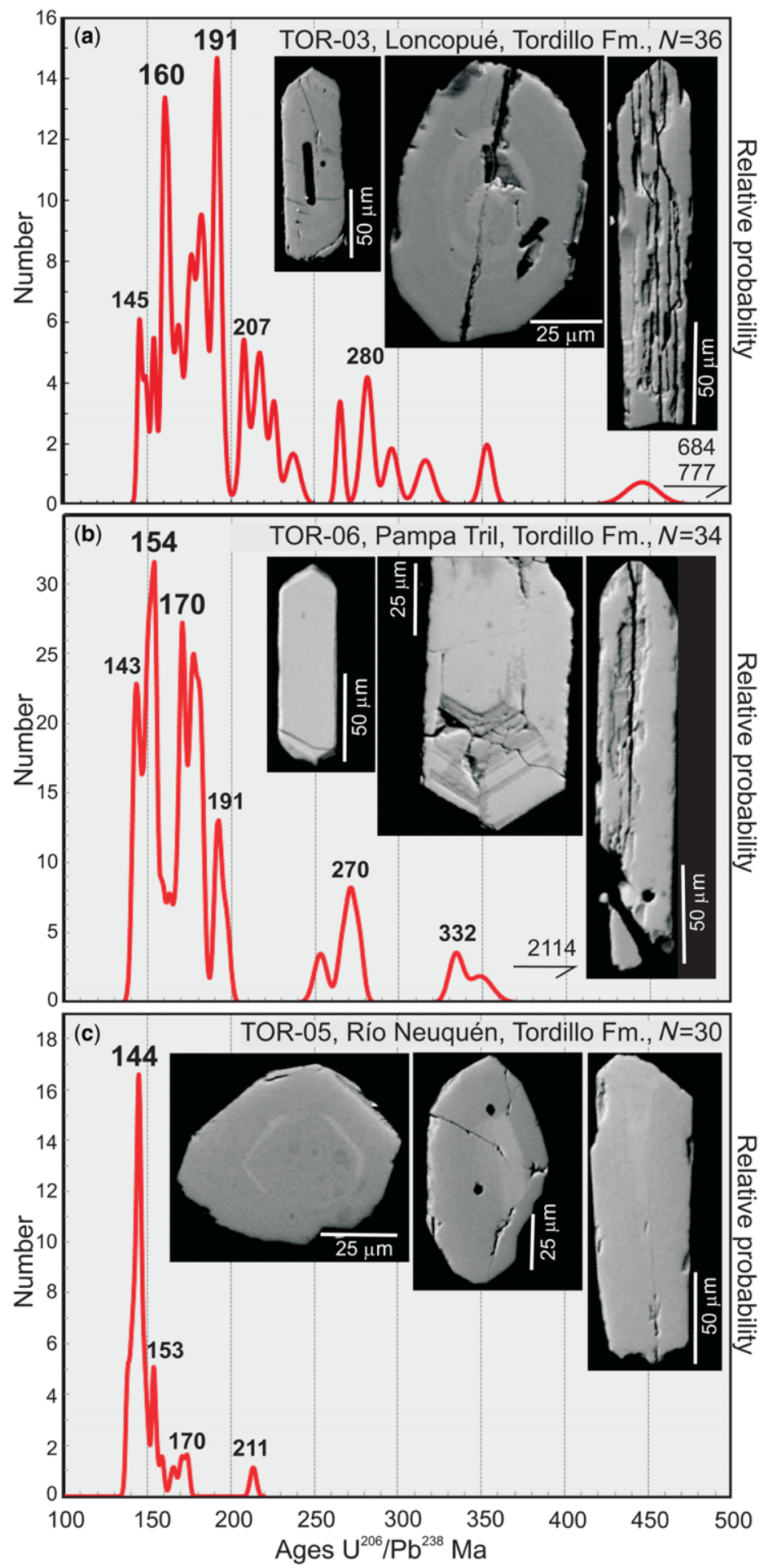

Fig. 9. Relative probability curves of $\mathrm{Pb}^{206}-\mathrm{U}^{238}$ ages on detrital zircons from the Tordillo Formation: (a) TOR-03, (b) TOR-06 and (c) TOR-05. Inset are BSE images from the study samples. 

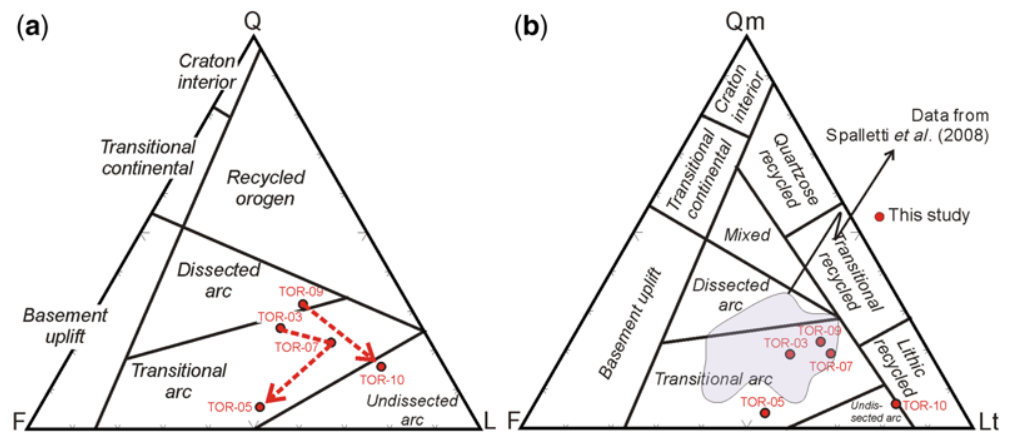

Fig. 10. Provenance data from petrography of the Tordillo Formation using the schemes of Dickinson et al. (1983): (a) quartz, feldspar and lithic fragments (Q, F, L); (b) monocrystalline quartz, feldspar, total lithic grains (Qm, F, Lt).

2007). However, palaeocurrent measurements in the southwestern depocentre indicate an orientation of drainage opposed to the Somún Curá Massif (Zavala et al. 2005). Consequently, the source region of detrital material supplied should be the Huincul High. This basement high might also have acted as a barrier to sediment provenance from further south (Naipauer et al. 2012).

\section{Regional and temporal changes in the} sedimentary provenance of the Tordillo

\section{Formation}

Detailed analysis of the sandstone petrography and patterns of the detrital zircon ages suggests important regional and temporal changes in the sedimentary provenance for the Tordillo Formation.

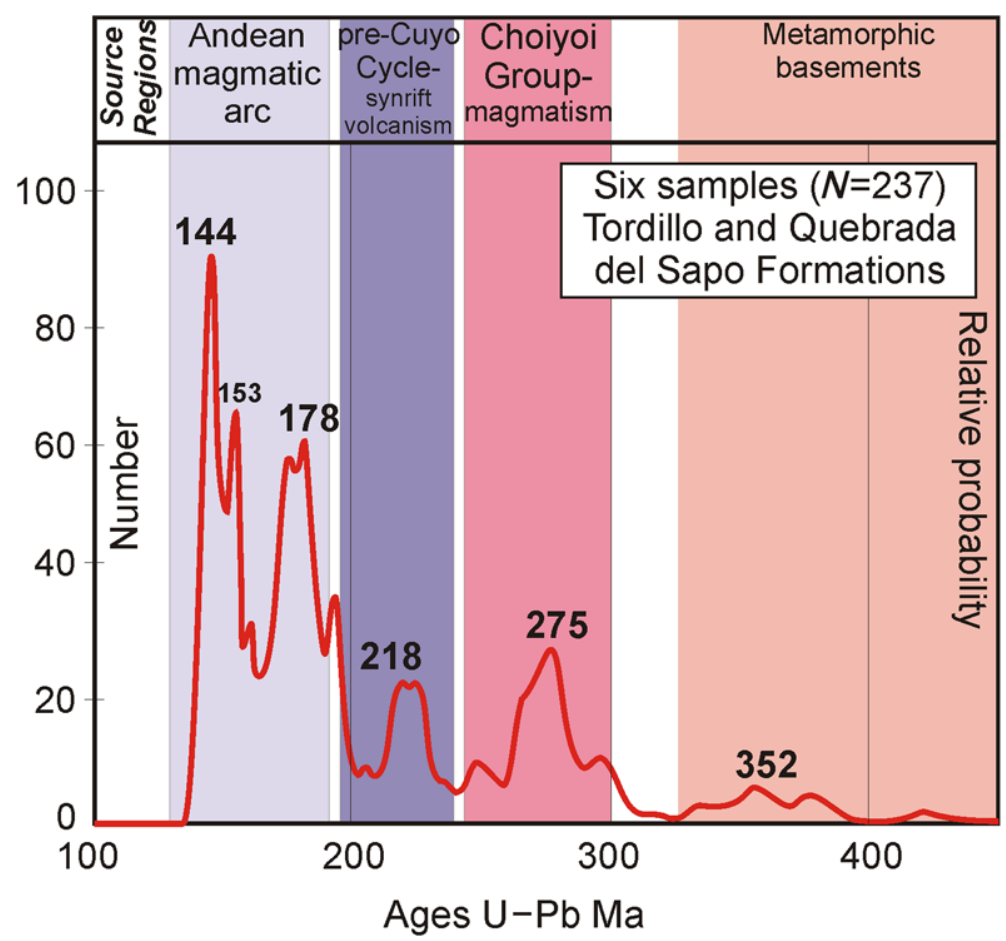

Fig. 11. Summary of the $\mathrm{U}-\mathrm{Pb}$ zircon ages for all the samples analysed in the Tordillo Formation: TOR-03, TOR-05, TOR-06, TOR-07, TOR-09 and TOR-10. Within the main peaks of ages, the possible source areas are interpreted. 
From an initial examination, two different source areas are distinguished based on the amount of polycrystalline quartz and differences in the lithic composition. The samples from the southwestern depocentre have higher amounts of polycrystalline quartz, probably related to the presence of a metamorphic source. This metamorphic source is also seen in the detailed composition of the rock fragment framework. On the other hand, samples from the northwestern depocentre contain a large amount of monocrystalline quartz together with the larger amount of sedimentary and altered rock fragments. Although the proportion and composition of volcanic lithic fragments are similar in both depocentres, it is clear that in the southwestern depocentre the presence of metamorphic and vitric volcanic rock fragments indicates sources within the Huincul High or from the Patagonian Cordillera.

Analysing separately the volcanic lithic fragments in both depocentres, it becomes clear that there is a change in the proportion of acid v. basic textures, the acid textures (granular and seriate) being more common at the base of the unit and the basic textures (microlithic and lathwork) more common at the top. This temporal variation could be interpreted as a change of the volcanic rock source from the Choiyoi magmatic province at the base to the Andean magmatic arc at the top. If we analyse the southwestern depocentre, the provenance changes from a dissected to an undissected arc (Fig. 10b). Analysing the northwestern depocentre, a similar pattern is observed, with sources of sediments changing from a dissected to a transitional arc (Fig. 10b).

The detailed analyses of the patterns of the detrital zircon ages are consistent with petrographic studies. Samples TOR-03, TOR-07 and TOR-09 taken from the base of the sequence are characterized by the predominance of Carboniferous to Early Jurassic zircon ages, representing more than $50 \%$ of the total number of grains for each sample (Fig. 12). The Late Triassic to Early Jurassic ages (pre-Cuyo Cycle) are represented by $40 \%$ of the zircon grains, and the relative abundances of the less frequent Late Palaeozoic ages (Choiyoi Group) are between 14 and 36\%. The Precambrian to Early Palaeozoic ages $(<11 \%)$ indicate less important metamorphic sources (Fig. 12). These samples also have Middle to Upper Jurassic detrital zircon grains with abundance of less than $40 \%$. Samples from the top of the sequence have a predominance of zircon ages from the Mid to Early Jurassic (TOR-06, 62\%; TOR-05, 97\%), and the older ages that characterize the basal units disappear (Fig. 12). This temporal variation in the provenance of the detrital zircons suggests that, at the beginning of the sedimentation, Carboniferous to Lower Jurassic magmatic rocks and minor Precambrian to Lower Palaeozoic metamorphic areas were the most important sources. Towards the top of the sequence the basement rocks seem to have been eroded or were covered, while the Andean magmatic arc becomes much more important, predominating as the main source region (Fig. 12).

There are also some variations in the provenance patterns according to sample location (Fig. 12). In the northwestern depocentre (samples TOR-03, TOR-05, TOR-6 and TOR-07) the Andean arc sources are predominant, while in the southwestern depocentre (samples TOR-09 and TOR-10) basement sources (pre-Cuyo Cycle, Choiyoi Group and metamorphic complexes) are more prominent, but there are also maximum peaks indicating sources in the Andean arc (Fig. 12). The complete $\mathrm{U}-\mathrm{Pb}$ dataset confirms the relevance of the Huincul deformation zone as a positive topographic region in the southern part of the basin, which acted as a source area during the Late Jurassic and also divided the Neuquén Basin into two depocentres (Naipauer et al. 2012).

\section{Changes in the provenance patterns and the tectonic evolution of the}

\section{Neuquén Basin}

Several second-order lowstand wedges were recognized in the Neuquén Basin during the retroarc stage (Jurassic to Early Cretaceous) (Howell et al. 2005; Spalletti \& Veiga 2007). The patterns of detrital zircon ages in the Kimmeridgian (Tordillo Formation) and the Hauterivian (Avilé Member of the Agrio Formation; Fig. 2) lowstands show significant differences. These are shown by the variations in the relative frequency peaks corresponding to maximum contributions from the Andean magmatic arc, from the basements of the basin or from the eastern foreland regions (Fig. 13).

A lowstand wedge is developed during the Late Jurassic in the Kimmeridgian to early Tithonian, represented by the Tordillo Formation (Spalletti \& Veiga 2007). This stage is characterized by detrital zircon supply from the Andean magmatic arc, which is coeval or a little older than the sedimentation. Local variations in the patterns of detrital zircon ages occur principally at the beginning of sedimentation and in the Huincul deformation zone south of the basin (Fig. 11).

A major inundation of the Neuquén Basin occurred after the Kimmeridgian lowstand wedge that marked the beginning of the marine deposition of the Mendoza Group (Legarreta \& Uliana 1991). However, another important lowstand wedge was developed in the Hauterivian during the deposition 


\section{NORTHWESTERN DEPOCENTRE}

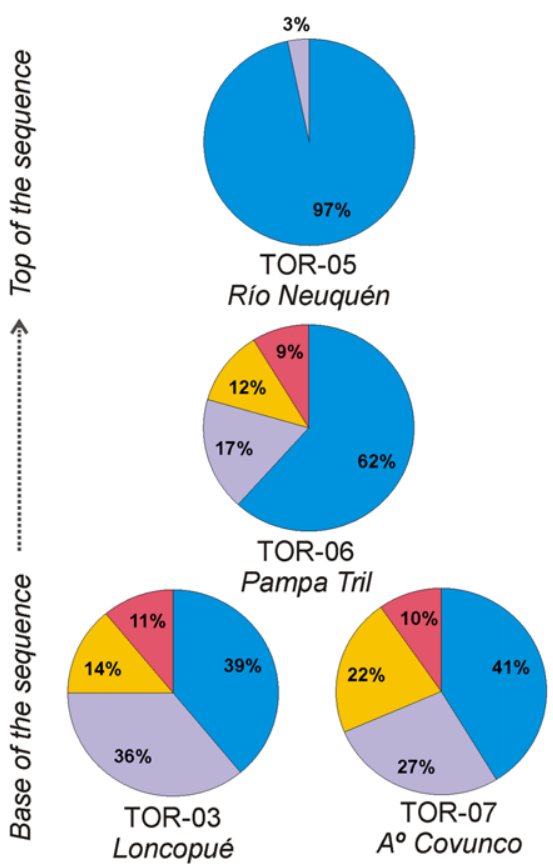

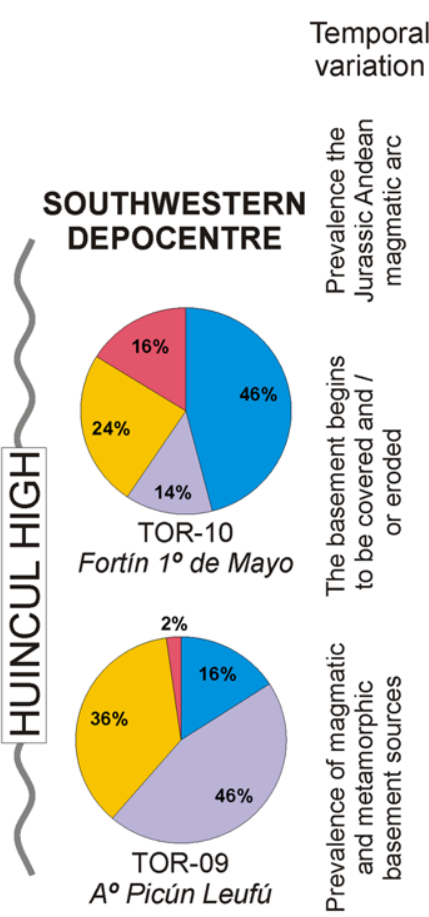

Temporal

Main population of the detrital zircon ages

Possible source regions

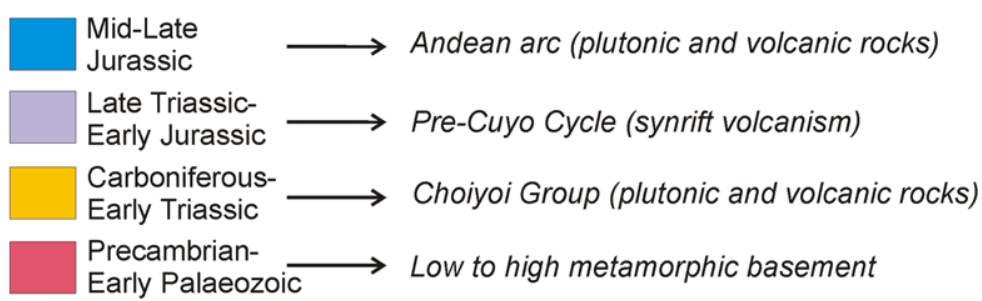

Fig. 12. Pie diagrams showing, in percentages, the main populations of detrital zircon ages and their possible source areas in the Neuquén Basin.

of the Agrio Formation. This is represented by the Avilé Member (Legarreta \& Gulisano 1989; Veiga et al. 2007, 2011). Two fluvial sandstones at the base of this member were dated by $\mathrm{U}-\mathrm{Pb}$ SHRIMP on detrital zircons (Tunik et al. 2010); these samples were taken in Tricao Malal and Pichaihue in the western central part of the basin (Fig. 13), where fluvial depositional systems dominate (Veiga et al. 2011). Detrital zircons from this member show a significant change in the age pattern in comparison with the Tordillo Formation. The Hauterivian lowstand wedge has a decrease in the relative abundance of the Late Jurassic and Cretaceous zircon ages, as well as an increase in the abundance of the older ages (Tunik et al.
2010). The prominent age peaks show provenance from the synrift volcanism (pre-Cuyo Cycle), from the basement of the basin (Choiyoi Group) and from the eastern foreland cratonic region (Grenvillian, Pampean and Famatinian magmatic arcs) (Fig. 13). This provenance pattern is probably linked with the growth of topographic barriers such as the Huincul High in the south or the Cordillera del Viento range in the NW. Although there are no Late Jurassic and Early Cretaceous detrital zircon ages in the Avilé Member, petrographic studies have demonstrated that the magmatic arc supplied volcanic material into the basin during the Early Cretaceous (Eppinger \& Rosenfeld 1996). This source is only detected in the fall tuff 


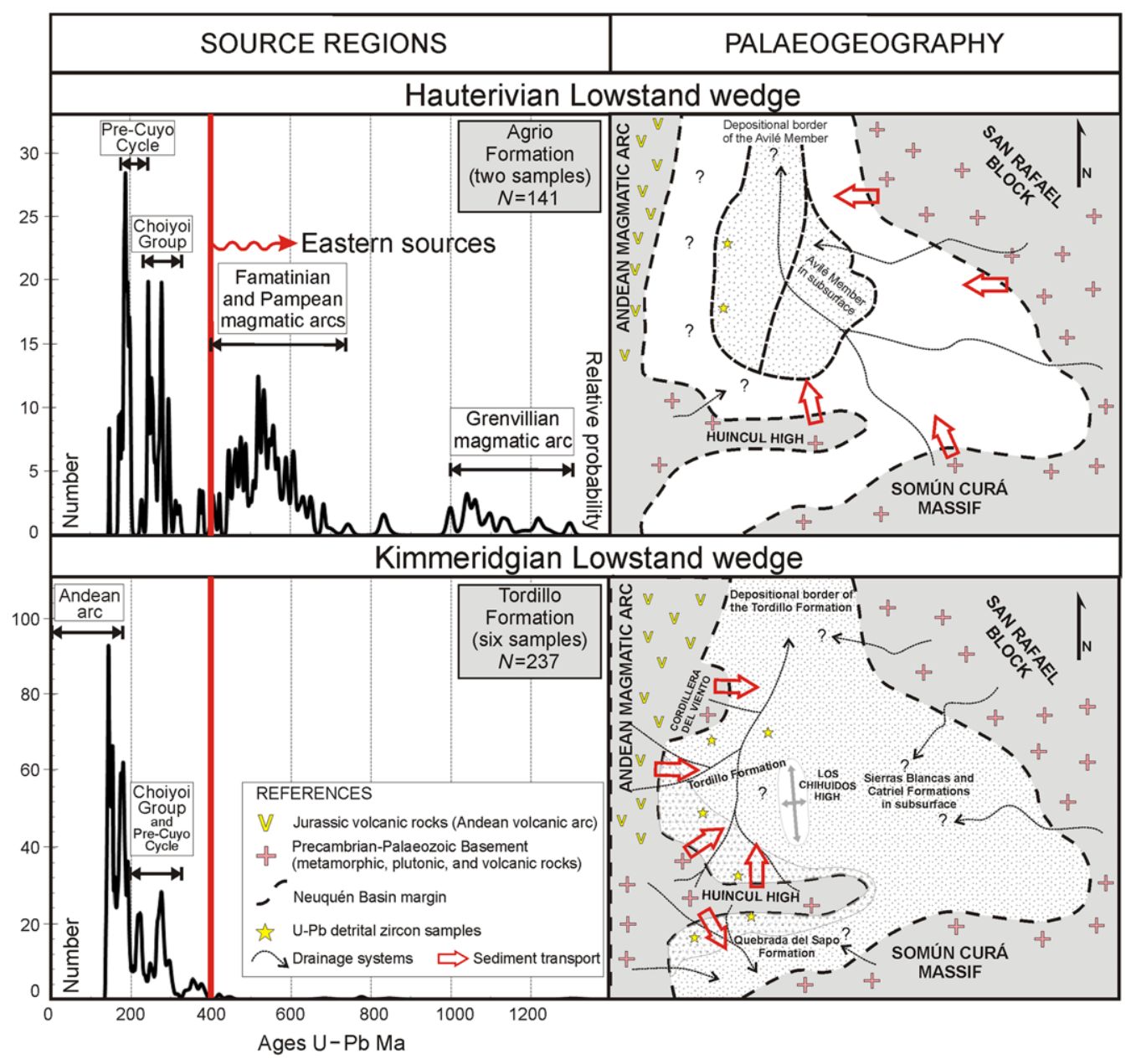

Fig. 13. Summary of the $\mathrm{U}-\mathrm{Pb}$ zircon ages for all the samples from the Tordillo Formation and the Avilé Member of the Agrio Formation with the Kimmeridgian and Hauterivian lowstand wedges palaeogeography in the Neuquén Basin. Note the potential source areas for the basin: a western magmatic arc and emerged areas along the east-west oriented Huincul deformational zone as well as northeastern and southeastern basement margins.

layers of the Agrio Formation (Aguirre-Urreta et al. 2008). Consequently, the present data suggest that the major changes in the patterns of detrital zircon ages during the Late Jurassic and Early Cretaceous possibly reflect global sea-level changes and could also be a result of positive topographic sediment barriers.

Our zircon data confirm previous studies by Legarreta \& Uliana (1991) for the Kimmeridgian lowstand wedge. They interpreted that the arc played a considerable role as a source region during sea-level lowstands, but this has not been recognized in the less significant Hauterivian lowstand wedge where the foreland cratonic area acted as the main source region.

\section{Maximum depositional and minimum biostratigraphic ages}

The youngest $\mathrm{U}-\mathrm{Pb}$ ages of detrital zircons are commonly used to constrain the maximum depositional ages of Precambrian and metamorphic sedimentary rocks where the fossiliferous content is inconclusive (Fedo et al. 2003). It is also used in unfossiliferous Palaeozoic, Mesozoic and Cenozoic sequences. Dickinson \& Gehrels (2009) have proposed and discussed four alternative measures to constrain the maximum depositional age using thousands of $\mathrm{U}-\mathrm{Pb}$ data from Mesozoic sedimentary units with biostratigraphic age control. We discuss our data in terms of the two most 
statistically robust alternatives proposed by these authors.

One of the measures of the maximum depositional age is the youngest single grain age, although this age might be altered due to $\mathrm{Pb}$ loss (Dickinson $\&$ Gehrels 2009). In the analysed samples, the youngest single grain ages are 145.2 Ma (TOR03), 142.2 Ma (TOR-06) and 137.6 Ma (TOR-05).

The samples analysed from the southern part of the basin have younger single grain ages at c. 143.7 Ma (TOR-07), 147.5 Ma (TOR-09) and 140.2 Ma (TOR-10). Therefore, there are small variations among the analysed samples, and the younger ages (i.e. $137.6 \mathrm{Ma}$ ) are probably due to $\mathrm{Pb}$ loss, because their discordances are slightly higher (see tables in the Supplementary Material).

The second most statistically robust approach is to considerer the youngest graphical age peak as the most reliable maximum age (Dickinson \& Gehrels 2009), which in the Tordillo Formation is at c. $145 \mathrm{Ma}$ (TOR-03), c. $143 \mathrm{Ma}$ (TOR-06) and c. $144 \mathrm{Ma}$ (TOR-05). Samples from the southern part of the basin have similar maximum age peaks, but they are a little older: $c$. $144 \mathrm{Ma}$ (TOR-07) for the Tordillo Formation and $c$. $151 \mathrm{Ma}$ (TOR-09) and c. $150 \mathrm{Ma}$ (TOR-10) for the Quebrada del Sapo Formation. Moreover, the summary $\mathrm{U}-\mathrm{Pb}$ age probability curves for all six analysed samples (237 concordant ages) shows a statistically robust youngest age peak at c. $144 \mathrm{Ma}$ (Fig. 11). This result is in agreement with the individual youngest graphical age peak for each sample analysed and we consider it the most reliable value for the maximum depositional age for the Tordillo and Quebrada del Sapo formations.

The minimum relative age of the Tordillo Formation is well constrained by the concordant deposition of the overlying Vaca Muerta Formation. The age of the base of this unit is late early Tithonian while the top is early Valanginian, based on its abundant ammonoid fauna and other biostratigraphic markers (Leanza 1981; Riccardi 2008a, b; Leanza et al. 2012; Aguirre-Urreta et al. 2011). According to the chronostratigraphic Mesozoic timescale of Ogg (2004), the boundaries of the Tithonian are, at the base, $150.8 \pm 4 \mathrm{Ma}$ and, at the top, $145.5 \pm 4 \mathrm{Ma}$ (Fig. 2), the latter being the present absolute age for the Jurassic-Cretaceous boundary accepted by the International Commission of Stratigraphy of the IUGS (Ogg 2004). Recent studies by Ogg \& Hinnov (2012), moved the base of the Tithonian to an older age, and propose a limit at $152.1 \mathrm{Ma}$. However, in the Tordillo Formation, the $\mathrm{U}-\mathrm{Pb}$ detrital zircon ages indicate a statistically robust measure of the maximum depositional age at $c$. $144 \mathrm{Ma}$. This absolute age is at least $7 \mathrm{Ma}$ younger than the value in the chronostratigraphic Mesozoic timescale.
It should be noted that $\mathrm{U}-\mathrm{Pb}$ detrital zircon ages separated from the Lagunillas Formation, which is the temporal and facies equivalent to the Tordillo Formation in the Tarapacá Basin, northern Chile, yielded a group of younger ages between 148.5 \pm 5.1 and $144.6 \pm 3.5 \mathrm{Ma}$ (Oliveros et al. 2012). Furthermore, volcanic zircons separate from ignimbrite and tuff levels interlayered in this volcaniclastic sequence yielded similar ages between $c$. 144 and $151 \mathrm{Ma}$ (Labbé et al. 2012, and references therein). This age group is the equivalent to that found in the younger population of zircons from the Tordillo Formation.

Moreover, south of the Neuquén Basin, between $43^{\circ} \mathrm{S}$ and $55^{\circ} \mathrm{S}$ in Chilean and Argentinian Patagonia, another retroarc basin known as the Austral Basin was developed. In the northwestern region a marine transgression started in the Tithonian until the early Hauterivian with the deposition of volcanic sandstone and pelitic successions with ammonoid and bivalve faunas (De La Cruz et al. 1996). The marine sediments cover a thick sequence of volcanic rocks named the Ibáñez Formation from the Mid to Late Jurassic. These volcanic rocks were recently dated by $\mathrm{U}-\mathrm{Pb}$ SHRIMP on zircons at $c$. 136$140 \mathrm{Ma}$ (Suárez et al. 2009). These ages also show a discrepancy between the radiometric ages and the biostratigraphy for the Late Jurassic to Early Cretaceous in the Austral Basin. This discrepancy seems to extend through several basins in the southwestern Andean margin.

Pálfy et al. (2000) also clearly exposed the discrepancies in the absolute ages for the Jurassic stage boundaries and they presented new $\mathrm{U}-\mathrm{Pb}$ and $\mathrm{Ar} / \mathrm{Ar}$ ages. The proposed upper Tithonian boundary was at $c$. $141.8 \mathrm{Ma}$, which is more in accordance with the ages obtained in the Tordillo Formation from the Neuquén Basin. Geochronological work in progress on $\mathrm{U}-\mathrm{Pb}$ ages (TIMS and SHRIMP) in zircons separated from tuffs interlayered in fossiliferous sequences of the Vaca Muerta Formation will shed further light on this discussion.

\section{Implications}

(1) The summary of $\mathrm{U}-\mathrm{Pb}$ detrital zircon age probability curves for all analysed samples for the Tordillo Formation indicates that the most important sediment source was the Jurassic Andean magmatic arc (peaks at c. 144, c. 153 and c. $178 \mathrm{Ma}$ ). Also, two secondary source regions are defined according to the prominent peaks at c. 218 and $c .275 \mathrm{Ma}$, which are consistent with ages from the pre-Cuyo Cycle and the Choiyoi magmatic province, respectively. Less abundant age 
groups from the Early Palaeozoic to Precambrian could represent evidence of metamorphic basement sources for the basin.

(2) Temporal and regional changes in the provenance patterns were defined in the Tordillo Formation. The temporal variation indicates that, at the beginning of sedimentation, Carboniferous to Lower Jurassic magmatic rocks and Precambrian to Lower Palaeozoic metamorphic basement rocks were the most important sources of sediment supply. Towards the top of the unit the basement rocks were eroded and/or covered, and the Andean magmatic arc becomes the main source region. Some geographic variations in the provenance patterns throughout the basin were also indentified; in the northwestern depocentre the Jurassic arc is the predominant source, but in the southwestern depocentre the basement sources (pre-Cuyo Cycle, Choiyoi Group and metamorphic complex) are the most important, although there are also significant zircon ages from the Late Jurassic arc. This confirms the relevance of the Huincul deformation zone as a positive element and source region in the southern part of the Neuquén Basin for the Jurassic.

(3) The comparison between the provenance patterns from the Kimmeridgian and the Hauterivian lowstand wedges showed that the major changes are possibly related to global sea-level changes and the growth of topographic barriers such as the Huincul High in the south or the Cordillera del Viento range in the NW. Our zircon data confirm that the arc region played a considerable role as a source region for the Tordillo Formation during these sea-level lowstands. However, it is not possible to recognize this arc source in the smaller Hauterivian lowstand wedge. In the Avilé Member of the Agrio Formation, the Late Jurassic and Cretaceous zircon ages are not present and therefore the foreland area acted as the main source. Possibly, the lack of the Andean detrital zircons in the Avilé Member indicates that the volcanic arc was retracted to the trench at this time.

(4) The results obtained show a statistically robust measure of the maximum deposition age for the Tordillo Formation. We used the youngest graphical age peak and this is defined by a prominent peak composed of 37 concordant zircon ages at $c$. $144 \mathrm{Ma}$. This younger age indicates a discrepancy of at least 7 Ma with the absolute ages for the Kimmeridgian and Tithonian boundaries from the chronostratigraphic timescale of Ogg \& Hinnov (2012). This also raises questions about the true absolute age of the JurassicCretaceous boundary. However, these younger ages are more in accordance with the ages obtained by Pálfy et al. (2000) where the upper Tithonian boundary was proposed at 141.8 Ma.

Maximiliano Naipauer acknowledges the financial support of CONICET, the Bunge \& Born Foundation and ANPCyT PICT-2010-2099, Argentina. Marcio Pimentel acknowledges continuous financial support from $\mathrm{CNPq}$, Brazil. B. Aguirre-Urreta and E. García Morabito are thanked for their comments and suggestions for the final version of the manuscript. We would like to thank the two anonymous referees for providing us with constructive comments and suggestions. This is contribution R-81 of the Instituto de Estudios Andinos 'Don Pablo Groeber' (CONICET-UBA).

\section{References}

Aguirre-Urreta, B. \& Rawson, P. F. 2012. Lower Cretaceous ammonites from the Neuquén Basin, Argentina: a new heteromorph fauna from the uppermost Agrio Formation. Cretaceous Research, 35, $208-216$.

Aguirre-Urreta, B., Lazo, D. G. et AL. 2011. Megainvertebrados del Cretácico y su importancia bioestratigráfica. In: Leanza, H. A., Arregui, C., Carbone, O., Danieli, J. C. \& Vallés, J. M. (eds) Geología y Recursos Naturales de la Provincia de Neuquén. Relatorio del VXIII Congreso Geológico Argentino, Buenos Aires, 465-488.

Aguirre-Urreta, M. B. \& Rawson, P. F. 1999. Stratigraphic position of Valanginites, Lissonia and Acantholissonia in the Lower Valanginian (Lower Cretaceous) sequence of the Neuquén Basin, Argentina. In: Olóriz, F. \& Rodriguez-Tovar, F. J. (eds) Advancing Research on Living and Fossil Cephalopods. Plenum Press, New York, 521-529.

Aguirre-Urreta, M. B., Pazos, P. J., Lazo, D. G., FAnNing, C. M. \& LiTVAK, V. D. 2008. First U-Pb SHRIMP age of the Hauterivian stage, Neuquén Basin, Argentina. Journal of South American Earth Sciences, 26, 91-99.

Albarede, F., Telouk, P., Blichert-Toft, J., Boyet, M., Agranier, A. \& Nelson, B. 2004. Precise and accurate isotopic measurements using multiplecollector ICPMS. Geochimica et Cosmochimica Acta, 68, 2725-2744.

Bahlburg, H., Vervoort, J. D., Du Frane, S. A., Bock, B., Augustsson, C. \& Reimann, C. 2009. Timing of crust formation and recycling in accretionary orogens: insights learned from the western margin of South America. Earth-Science Reviews, 97, 215-241.

Bahlburg, H., Vervoort, J. D. \& Du Frane, S. A. 2010. Plate tectonic significance of Middle Cambrian and Ordovician siliciclastic rocks of the Bavarian Facies, Armorican Terrane Assemblage, Germany - U-Pb and Hf isotope evidence from detrital zircons. Gondwana Research, 17, 223-235. 
Buhn, B., Pimentel, M. M., Matteini, M. \& Dantas, E. 2009. High spatial resolution analysis of $\mathrm{Pb}$ and $\mathrm{U}$ isotopes for geochronology by laser ablation multicollector inductively coupled plasma mass spectrometry (LA-MC-ICP-MS). Anais da Academia Brasileira de Ciências, 81, 99-114.

Carbone, O., Franzese, J., Limeres, M., Delpino, D. \& Martínez, R. 2011. El Ciclo Precuyano (Triásico Tardío - Jurásico Temprano) en la Cuenca Neuquina. In: Leanza, H. A., Arregui, C., Carbone, O., DANieli, J. C. \& VAllés, J. M. (eds) Geología y Recursos Naturales de la Provincia de Neuquén. Relatorio del VXIII Congreso Geológico Argentino, Buenos Aires, 63-75.

Castro, A., Moreno-Ventas, I. et al. 2011. Petrology and SHRIMP U-Pb zircon geochronology of Cordilleran granitoids of the Bariloche area, Argentina. Journal of South American Earth Sciences, 32, 508-530.

Charrier, R., Pinto, L. \& Rodríguez, M. 2007. Tectonostratigraphic evolution of the Andean Orogen in Chile. In: Gibbonds, W. \& Moreno, T. (eds) The Geology of Chile. Geological Society, London, Special Publications, 21-116.

Cingolani, C., Dalla Salda, L., Hervé, F., Munizaga, F., Pankhurst, R. J., Parada, M. A. \& Rapela, C. W. 1991. The magmatic evolution of northern Patagonia; new impressions of pre-Andean and Andean tectonics. In: Harmon, R. S. \& Rapela, C. W. (eds) Andean Magmatism and its Tectonic Setting. Geological Society of America, Boulder, CO, Special Papers, 265, 29-44.

Cingolani, C. A., Zanettini, J. C. M. \& Leanza, H. A. 2011. El basamento ígneo metamórfico. In: LEANZA, H. A., Arregui, C., Carbone, O., Danieli, J. C. \& VAllés, J. M. (eds) Geología y Recursos Naturales de la Provincia de Neuquén. Relatorio del VXIII Congreso Geológico Argentino, Buenos Aires, 37-47.

De La Cruz, R., Suárez, M., Covacevich, V. \& Quiroz, D. 1996. Estratigrafía de la zona de Palena y Futaleufú $\left(43^{\circ} 15^{\prime}-43^{\circ} 45^{\prime}\right.$ Latitud S), X Región, Chile. XIII Congreso Geológico Argentino and III Congreso de Exploración de Hidrocarburos, Buenos Aires, Actas, I, 417-424.

Dickinson, W. R. \& Gehrels, G. E. 2009. Use of U-Pb ages of detrital zircons to infer maximum depositional ages of strata: a test against a Colorado Plateau Mesozoic database. Earth and Planetary Science Letters, 288, $115-125$.

Dickinson, W. R., Beard, L. S. ET AL. 1983. Provenance of North American Phanerozoic sandstone in relation to tectonic setting. Geological Society of American Bulletin, 94, 222-235.

Di Giulio, A., Ronchi, A., Sanfilippo, A., Tiepolo, M., Pimentel, M. \& Ramos, V. A. 2012. Detrital zircon provenance from the Neuquén Basin (South Central Andes): Cretaceous geodynamic evolution and sedimentary response in a retroarc-foreland basin. Geology, 40, 559-562.

Digregorio, J. H. 1972. Neuquén. In: Leanza, H. F. (ed.) Geología Regional Argentina. Academia Nacional de Ciencias, Córdoba, 439-505.

Digregorio, R. E., Gulisano, C. A., GutiérrezPleimling, A. R. \& Minitti, S. A. 1984. Esquema de la evolución geodinámica de la Cuenca Neuquina y sus implicancias paleogeográficas. IX Congreso Geológico Argentino, San Carlos de Bariloche, Actas, II, $147-162$

DotT, R. H. 1964. Wacke, greywacke and matrix - what approach to immature sandstone classification? Journal of Sedimentary Petrology, 34, 625-632.

EPPINGER, K. J. \& Rosenfeld, U. 1996. Western margin and provenance of sediments of the Neuquén Basin (Argentina) in the Late Jurassic and Early Cretaceous. Tectonophysics, 259, 229-244.

Fedo, C. M., Sircombe, K. N. \& Rainbird, R. H. 2003. Detrital zircon analysis of the sedimentary record. In: HanchaR, J. M. \& Hoskin, P. W. O. (eds) Zircon, Reviews in Mineralogy and Geochemistry. Mineralogical Society of America, Washington DC, $\mathbf{5 3}$ 277-303.

Folk, R. L., ANDrews, P. B. \& Lewis, D. W. 1970. Detrital sedimentary rock classification and nomenclature for use in New Zealand. New Zealand Journal of Geology and Geophysics, 13, 937-968.

Franzese, J. R. 1995. El Complejo Piedra Santa (Neuquén, Argentina): parte de un cinturón metamórfico neopalaeozoico del Gondwana suroccidental. Revista Geológica de Chile, 22, 193-202.

Franzese, J. R. \& Spalletti, L. A. 2001. Late Triassicearly Jurassic continental extension in southwestern Gondwana: tectonic segmentation and pre-break-up rifting. Journal of South American Earth Sciences, 14, 257-270.

Franzese, J. R., Veiga, G. D., Schwarz, E. \& GómezPÉREZ, I. 2006. Tectono-stratigraphic evolution of a Mesozoic graben border system: the Chachil depocentre, southern Neuquén Basin, Argentina. Journal of the Geological Society, London, 163, 207-221.

Groeber, P. 1946. Observaciones geológicas a lo largo del meridiano 70. 1. Hoja Chos Malal. Revista de la Sociedad Geológica Argentina, 1, 177-208.

Gulisano, C. A. 1981. El ciclo cuyano en el norte de Neuquén y sur de Mendoza. XVIII Congreso Geológico Argentino, San Juan, Actas, III, 573-592.

Gulisano, C. A. 1988. Análisis estratigráfico y sedimentológico de la Formación Tordillo en el oeste de la Provincia del Neuquén, Cuenca Neuquina, Argentina. $\mathrm{PhD}$ thesis, Facultad de Ciencias Exactas y Naturales, Universidad de Buenos Aires.

Gulisano, C. A. \& Gutiérrez Pleimling, A. R. 1995. Field guide: the Jurassic of the Neuquén Basin. a) Neuquén province. Asociación Geológica Argentina, Buenos Aires, Serie E, 1-111.

Gulisano, C. A., Gutiérrez Pleimling, A. R. \& DigreGORIO, R. E. 1984. Esquema estratigráfico de la secuencia jurásica del oeste de la Provincia de Neuquén. IX Congreso Geológico Argentino, San Carlos de Bariloche, Actas, I, 236-259.

Howell, J. A., Schwarz, E., Spalletti, L. A. \& Veiga, G. D. 2005. The Neuquén Basin: an overview. In: Veiga, G. D., Spalletti, L. A., Howell, J. A. \& Schwarz, E. (eds) The Neuquén Basin, Argentina: A Case Study in Sequence Stratigraphy and Basin Dynamics. Geological Society, London, Special Publications, 252, 1-14.

Jackson, S. E., Pearson, N. J., Griffin, W. L. \& BelouSova, E. A. 2004. The application of laser ablationinductively coupled plasma-mass spectrometry to in 
situ $\mathrm{U}-\mathrm{Pb}$ zircon geochronology. Chemical Geology, 211, 47-69.

Kamo, S. L. \& Riccardi, A. C. 2009. A new U-Pb zircon age for an ash layer at the Bathonian-Callovian boundary, Argentina. GFF, 131, 177-182.

Košler, J., Fonneland, H., Sylvester, P., Tubrett, M. \& Pedersen, R. B. 2002. U-Pb dating of detrital zircons for sediment provenance studies - a comparison of laser ablation ICP-MS and SIMS techniques. Chemical Geology, 182, 605-618.

Labbé, M., Salazar, E., Rossel, P., Merino, R. \& OliVERos, V. 2012. Variaciones laterales en la arquitectura estratigráfica del Juráscio Superior en el valle del Tránsito: ¿Evidencias del desarrollo de un rift continental? XIII Congreso Geológico Chileno, Antofagasta, Actas, 718-720.

LeanZA, H. A. 1981. The Jurassic-Cretaceous boundary beds in West Central Argentina and their ammonite zones. Neues Jahrbuch für Geologie und Paläontologie, Abhandlungen, 161, 62-92.

Leanza, H. A. 1992. Estratigrafía del Paleozoico y Mesozoico anterior a los Movimientos Intermálmicos en la comarca del cerro Chachil, provincia del Neuquén. Revista de la Asociación Geológica Argentina, 45, 272-299.

Leanza, H. A., Sattler, F., Martinez, R. S. \& Carbone, O. 2012. La Formación Vaca Muerta y equivalentes (Jurásico Tardío-Cretácico Temprano) en la Cuenca Neuquina. In: Leanza, H. A., Arregui, C., Carbone, O., Danieli, J. C. \& VAllés, J. M. (eds) Geología y Recursos Naturales de la Provincia de Neuquén. Relatorio del VXIII Congreso Geológico Argentino, Buenos Aires, 113-129.

Legarreta, L. \& Gulisano, C. A. 1989. Análisis estratigráfico secuencial de la Cuenca Neuquina (Triásico superior-Terciario inferior, Argentina). In: Chebli, G. \& Spalletti, L. (eds) Cuencas Sedimentarias Argentinas. Universidad Nacional de Tucumán, Tucumán, Serie Correlación Geológica, 6, 221-243.

Legarreta, L. \& Uliana, M. A. 1991. Jurassic-Cretaceous marine oscillations and geometry of backarc basin fill, central Argentine Andes. In: Macdonald, D. I. M. (ed.) Sedimentation, Tectonics and Eustasy, Sea Level Changes at Active Plate Margins. International Association of Sedimentologists, Oxford, Special Publications, 12, 429-450.

Legarreta, L. \& Uliana, M. A. 1999. EL Jurásico y Cretácico de la Cordillera Principal y Cuenca Neuquina. In: Caminos, R. (ed.) Geología Argentina. Instituto de Geología y Recursos Minerales, Buenos Aires, Anales, 29, 399-432.

Llambías, E. J. \& Sato, A. M. 2011. Ciclo Gondwánico: la provincia magmática Choiyoi en Neuquén. In: LEANZA, H. A., Arregui, C., Carbone, O., Danieli, J. C. \& VALlÉs, J. M. (eds) Geología y Recursos Naturales de la Provincia de Neuquén. Relatorio del VXIII Congreso Geológico Argentino, Buenos Aires, 53-62.

Llambías, E. J., Leanza, H. A. \& Carbone, O. 2007. Evolución tectono-magmática durante el Pérmico al Jurásico Temprano en la Cordillera del Viento $\left(37^{\circ} 05^{\prime} \mathrm{S}-37^{\circ} 15^{\prime} \mathrm{S}\right)$ : nuevas evidencias geológicas y geoquímicas del inicio de la cuenca Neuquina. Revista de la Asociación Geológica Argentina, 62, 217-235.
López-Gómez, J., Martín-Chivelet, J. \& Palma, R. M. 2009. Architecture and development of the alluvial sediments of the Upper Jurassic Tordillo Formation in the Cañada Ancha Valley, northern Neuquén Basin, Argentina. Sedimentary Geology, 219, 180-195.

Lucassen, F., Trumbull, R., Franz, G., Creixell, C., VÁsquez, P., Romer, R. L. \& FigueroA, O. 2004. Distinguishing crustal recycling and juvenile additions at active continental margins: the Paleozoic to Recent compositional evolution of the Chilean Pacific margin $\left(36-41^{\circ} \mathrm{S}\right)$. Journal of South American Earth Sciences, 17, 103-119.

LUDWIG, K. R. 2003. Isoplot 3.00: a geochronological toolkit for Microsoft Excel. Berkeley Geochronological Center, Berkeley, CA, Special Publications, 4, 70.

Marchese, H. G. 1971. Litoestratigrafía y variaciones faciales de las sedimentitas mesozoicas de la Cuenca Neuquina, provincia de Neuquén, República Argentina. Revista de la Asociación Geológica Argentina, 26, 343-410.

Maretto, H., Carbone, O., Gazzera, C. \& Schiuma, M. 2002. Los reservorios de la Formación Tordillo. In: Schiuma, M., Hinterwimmer, G. \& Vergani, G. (eds) Rocas Reservorio de las Cuencas Productivas de la Argentinas. V Congreso de Exploración y Desarrollo de Hidrocarburos, Actas CD, Mar del Plata, 335-358.

Mescua, J. F., Giambiagi, L. B. \& Bechis, F. 2008. Evidencias de tectónica extensional en el Jurásico Tardío (Kimmeridgiano) del suroeste de la provincia de Mendoza. Revista de la Asociación Geológica Argentina, 63, 512-519.

Morton, A. C. \& Hallsworth, C. R. 1999. Processes controlling the composition of heavy mineral assemblages in sandstones. Sedimentary Geology, 124, $3-29$.

Mosquera, A. \& Ramos, V. A. 2006. Intraplate deformation in the Neuquén Embayment. In: KAY, S. M. \& Ramos, V. A. (eds) Evolution of an Andean Margin: A Tectonic and Magmatic View from the Andes to the Neuquén Basin $\left(35^{\circ}-39^{\circ}\right.$ lat $)$. Geological Society of America, Boulder, Special Papers, 407, 97-124.

Mpodozis, C. \& Ramos, V. A. 2008. Tectónica Jurásica en Argentina y Chile: extensión, subducción oblicua, rifting, deriva y colisiones? Revista de Asociación Geológica Argentina, 63, 481-497.

Mueller, P. A., Heatherington, A. L., Wooden, J. L., Shuster, R. D., Nutman, A. P. \& Williams, I. S. 1994. Precambrian zircons from the Florida basement: a Gondwana connection. Geology, 22, 119-122.

NaIPaUer, M., García Morabito, E. ET AL. 2012. Intraplate Late Jurassic deformation and exhumation in western central Argentina: constraints from surface data and $\mathrm{U}-\mathrm{Pb}$ detrital zircon ages. Tectonophysics, 524-525, 59-75.

OGG, J. G. 2004. The Jurassic period. In: Gradstein, F., OgG, J. \& Smith, A. (eds) A Geologic Time Scale. Cambridge University Press, Cambridge, 307-343.

OgG, J. G. \& Hinnov, L. A. 2012. The Jurassic Period. In: Gradstein, F. M., OGG, J. G., Schmitz, M. D. \& OGG, G. M. (eds) The Geologic Time Scale 2012. Elsevier, China, 731-791.

Oliveros, V., Labbé, M., Rossel, P., Charrier, R. \& EnCinAs, A. 2012. Late Jurassic paleogeographic 
evolution of the Andean back-arc basin: new constrains from the Lagunillas Formation, northern Chile $\left(27^{\circ} 30^{\prime}-38^{\circ} 30^{\prime}\right.$ S $)$. Journal of South American Earth Sciences, 37, 25-40.

PÁlfy, J., Smith, P. L. \& Mortensen, J. K. 2000. A U$\mathrm{Pb}$ and ${ }^{40} \mathrm{Ar} /{ }^{39} \mathrm{Ar}$ time scale for the Jurassic. Canadian Journal of Earth Sciences, 37, 923-944.

Pángaro, F., Veiga, R. \& Vergani, G. 2002. Evolución tecto-sedimentaria del área de Cerro Bandera, Cuenca Neuquina, Argentina. V Congreso de Exploración y Desarrollo de Hidrocarburos, CD-ROM, 16.

Pankhurst, R., Rapela, C., Fanning, C. \& Márquez, M. 2006. Gondwanide continental collision and the origin of Patagonia. Earth-Science Reviews, 76, $235-257$

Ramos, V. A. 1978. Estructura. VII Congreso Geológico Argentino, Relatorio, Neuquén, 99-118.

Ramos, V. A. 1999. Evolución tectónica de la Argentina. In: Caminos, R. (ed.) Geología Argentina. Instituto de Geología y Recursos Minerales, Buenos Aires, Anales, 29, 715-784.

Ramos, V. A. 2008. Patagonia: A Paleozoic continent adrift? Journal of South American Earth Sciences, 26, 235-251.

Ramos, V. A. 2010. The tectonic regime along the Andes: present-day and Mesozoic regimes. Geological Journal, 45, 2-25.

Ramos, V. A., García Morabito, E., Hervé, F. \& FAnNing, C. M. 2010. Grenville-age sources in Cuesta de Rahue, northern Patagonia: constrains from $\mathrm{U}-\mathrm{Pb} / \mathrm{SHRIMP}$ ages from detrital zircons. International Geological Congress on the Southern Hemisphere. Bollettino de Geofisica, 51, 42-44.

Ramos, V. A., Mosquera, A., Folguera, A. \& García Morabito, E. 2011. Evolución tectónica de los Andes y del Engolfamiento Neuquino adyacente. In: Leanza, H. A., Arregui, C., Carbone, O., Danieli, J. C. \& VAllés, J. M. (eds) Geología y Recursos Naturales de la Provincia de Neuquén. Relatorio del VXIII Congreso Geológico Argentino, Buenos Aires, 335-348.

Rapela, C. W., Spalletti, L. \& Merodio, J. 1983. Evolución magmática y geotectónica de la 'Serie Andesitica' andina (Paleoceno-Eoceno) en la Cordillera Norpatagónica. Revista de la Asociación Geológica Argentina, 38, 469-484.

Rapela, C. W., Dias, G., Franzese, J., Alonso, G. \& Benvenuto, A. 1991. El Batolito de la Patagonia Central: evidencias de un magmatismo triásico-jurásico asociado a fallas transcurrentes. Revista Geológica de Chile, 18, 121-138.

Rapela, C. W., Pankhurst, R. J., Fanning, C. M. \& Hervé, F. 2005. Pacific subduction coeval with the Karoo mantle plume: the Early Jurassic Subcordilleran belt of northwestern Patagonia. In: VAUGHaN, A. P. M., Leat, P. T. \& Pankhurst, R. J. (eds) Terrane Processes at the Margins of Gondwana. Geological Society, London, Special Publications, 246, 217-240.

RicCARDI, A. C. 1984. Las asociaciones de Amonites del Jurásico y Cretácico de Argentina. IX Congreso Geológico Argentino, San Carlos de Bariloche, Actas, IV, $569-595$

RICCARDI, A. C. 2008a. The marine Jurassic of Argentina: a biostratigraphic framework. Episodes, 31, 326-335.
RicCARDI, A. C. 2008b. El Jurásico de la Argentina y sus amonites. Revista de la Asociación Geológica Argentina, 63, 625-643.

Sato, A. M., Llambías, E. J., Basei, M. A. S. \& Leanza, H. A. 2008. The Permian Choiyoi Cycle in Cordillera del Viento (Principal Cordillera, Argentina): Over $25 \mathrm{Ma}$ of magmatic activity. VI South American Symposium on Isotope Geology, San Carlos de Bariloche, Proceedings in CD-ROM, 4.

Schiuma, M. \& Llambías, E. J. 2008. New ages and chemical analysis on Lower Jurassic volcanism close to the Huincul High, Neuquén. Revista de la Asociación Geológica Argentina, 63, 644-652.

Spalletti, L. A. \& Colombo Piñol, F. 2005. From alluvial fan to playa: an Upper Jurassic ephemeral fluvial system, Neuquén Basin, Argentina. Gondwana Research, 8, 363-383.

Spalletti, L. A. \& Veiga, G. D. 2007. Variability of continental depositional systems during lowstand sedimentation: an example from the Kimmeridgian of the Neuquén Basin, Argentina. Latin American Journal of Sedimentology and Basin Analysis, 14, 85-104.

Spalletti, L. A., Queralt, I., Matheos, S. D., Colombo, F. \& MagGi, J. 2008. Sedimentary petrology and geochemistry of siliciclastic rocks from the upper Jurassic Tordillo Formation (Neuquén Basin, western Argentina): implications for provenance and tectonic setting. Journal South American Earth Sciences, 25, 440-463.

Spalletti, L. A., Arregui, C. D. \& Veiga, G. D. 2011. La Formación Tordillo y equivalentes (Jurásico Tardío) en la Cuenca Neuquina. In: Leanza, H. A., Arregui, C., Carbone, O., Danieli, J. C. \& Vallés, J. M. (eds) Geología y Recursos Naturales de la Provincia de Neuquén. Relatorio del VXIII Congreso Geológico Argentino, Buenos Aires, 99-111.

StaceY, J. S. \& Kramers, J. D. 1975. Approximation of terrestrial lead isotope evolution by a two-stage model. Earth and Planetary Science Letters, 26, 207-221.

STIPANICIC, P. N. 1951. Sobre la presencia del Oxfordense superior en el arroyo de La Manga. Revista de la Asociación Geológica Argentina, 6, 213-239.

StiPAnicic, P. N. 1966. El Jurásico en Vega de la Veranda (Neuquén), el Oxfordense y el diastrofismo Divesiano (Agassiz-Yaila) en Argentina. Revista de la Asociación Geológica Argentina, 20, 403-478.

Stipanicic, P. N., Rodrigo, F., Baulies, O. L. \& MartíNEZ, C. G. 1968. Las Formaciones presenonianas en el denominado Macizo Nordpatagónico y regiones adyacentes. Revista de la Asociación Geológica Argentina, 23, 367-388.

Suárez, M., de la Cruz, R., Fanning, M. \& Etchart, H. 2008. Carboniferous, Permian and Toarcian magmatism in Cordillera del Viento, Neuquén, Argentina: first U-Pb SHRIMP dates and tectonic implications. XVII Congreso Geológico Argentino, San Salvador de Jujuy, Actas, 906-907.

Suárez, M., de la Cruz, R., Aguirre-Urreta, B. \& FANNING, M. 2009. Relationship between volcanism and marine sedimentation in northern Austral (Aisén) Basin, central Patagonia: stratigraphic, $\mathrm{U}-\mathrm{Pb}$ SHRIMP and paleontologic evidence. Journal of South American Earth Sciences, 27, 309-325. 
Tunik, M., Folguera, A., Naipauer, M., Pimentel, M. M. \& Ramos, V. A. 2010. Early uplift and orogenic deformation in the Neuquén Basin: constraints on the Andean uplift from $\mathrm{U}-\mathrm{Pb}$ and $\mathrm{Hf}$ isotopic data of detrital zircons. Tectonophysics, 489, $258-273$.

Varela, R., Basei, M. A. S., Cingolani, C. A., Siga, O., JR. \& PASSARELli, C. R. 2005. El basamento cristalino de los Andes Norpatagónicos en Argentina: geocronología e interpretación tectónica. Revista Geológica de Chile, 32, 167-187.

Veiga, G. D. \& Spalletti, L. A. 2007. The Upper Jurassic (Kimmeridgian) fluvial/aeolian systems of the southern Neuquén Basin, Argentina. Gondwana Research, 11, 286-302.

Veiga, G. D., Spalletti, L. A. \& Flint, S. S. 2007. Anatomy of a fluvial lowstand wedge: the Avilé Member of the Agrio Formation (Hauterivian) in central Neuquén Basin (NW Neuquén province), Argentina. In: Nichols, G., Williams, E. \& PaOla, C. (eds) Sedimentary Environments, Processes and Basins, A Tribute to Peter Friend. International Association of Sedimentologists, New Jersey, Special Publications, 38, 341-365.

Veiga, G. D., Spalletti, L. A. \& Schwarz, E. 2011. El Miembro Avilé de la Formaicón Agrio (Cretácico Temprano). In: Leanza, H. A., Arregui, C., Carbone, O., Danieli, J. C. \& Vallés, J. M. (eds) Geología y Recursos Naturales de la Provincia de Neuquén. Relatorio del VXIII Congreso Geológico Argentino, Buenos Aires, 161-173.
Vergani, G. D., Tankard, A. J., Belotti, H. J. \& WelsinK, H. J. 1995. Tectonic evolution and paleogeography of the Neuquén Basin, Argentina. In: TANKard, A. J., Suárez Soruco, R. \& Welsink, H. J. (eds) Petroleum Basins of South America. American Association of Petroleum Geologists, Tulsa, Memoirs, 62, 383-402.

Vicente, J. C. 2005. Dynamic paleogeography of the Jurassic Andean Basin: pattern of transgression and localization of main straits through the magmatic arc. Revista de la Asociación Geológica Argentina, 60, $221-250$.

Vicente, J. C. 2006. Dynamic paleogeography of the Jurassic Andean Basin: pattern of regression and general considerations on main features. Revista de la Asociación Geológica Argentina, 61, 408-437.

Weaver, C. E. 1931. Palaeontology of the Jurassic and Cretaceous of west central Argentina. Memoir of the University of Washington, 1, 594.

Zappettini, E. O., Méndez, V. \& Zanettini, J. C. M. 1987. Metasedimentitas mesopaleozoicas en el noroeste de la provincia del Neuquén. Revista de Asociación Geológica Argentina, 42, 206-207.

Zavala, C., Maretto, H. \& Di Meglio, M. 2005. Hierarchy of bounding surfaces in Aeolian sandstones of the Tordillo Formation (Jurassic). Neuquén Basin, Argentina. Geologica Acta, 3, 133-145.

ZuFfA, G. 1985. Optical analyses of arenites: influence of methodology on compositional results. In: ZuFFA, G. G. (ed.) Provenance of Arenites: NATO-ASI. Reidel Publication Company, Dordrecht, 148, 165-189. 